\title{
Beyond gender diversity: How specific attributes of female directors affect earning management
}

\author{
Ammar Ali Gull ${ }^{\text {a*, }}$ Mehdi Nekhili ${ }^{\text {a, b }}$, Tawhid Chtioui ${ }^{\text {c }}$ \& Haithem Nagati ${ }^{\text {b }}$ \\ ${ }^{\mathrm{a}}$ University of Maine (GAINS-ARGUMANS), France \\ ${ }^{b}$ ICD International Business School, France \\ ${ }^{c}$ Emlyon Business School, France
}

\begin{abstract}
We apply the system GMM regression estimation approach on a matched sample of French firms listed on Euronext Paris during the period 2001-2010 to investigate the relationship between female directors and earnings management by considering statutory and demographic attributes of women directors. Primarily, we find a negative relationship between female directors and the magnitude of earnings management. However, this result does not hold when statutory and demographic attributes of women directors are taken into account, because the assessment of earning quality requires particular competencies and skills. Our findings thus highlight that business expertise and audit committee memberships are key attributes of female directors that promote the effective monitoring of earnings management. In contrast, women leadership and experience are positively related to the level of earnings management. An important implication of our findings is that the decision to appoint females on corporate boards should be based on their statutory and demographic attributes rather than on blind implementation of gender quotas.
\end{abstract}

JEL Classification: J11, J16, M10, M40, M41

Keywords: Female directors; Statutory attributes; Demographic attributes; Earnings management 


\section{Introduction}

Earnings management is generally defined as the practice of using discretionary accounting methods to attain desired levels of reported earnings (Gavious, Segev, \& Yosef, 2012). Earnings management includes choosing accounting methods which provide reporting income that is advantageous for managers and the company but detrimental for external stakeholders (Krishnan \& Parsons, 2008). The issue of earnings quality is discussed extensively in the accounting literature, and is an important area of concern for stakeholders. Earnings quality shows the extent to which stated earnings reveal an organization's financial situation to interested parties. If users of financial data are "misled" by the level of reported income, then investors" allocation of resources may be inappropriate when based on the financial statements provided by management (Healy \& Wahlen, 1999). Managers are professionally responsible and ethically obliged to make sure that concerned parties receive high quality earnings reports in a timely manner (Krishnan \& Parsons, 2008). Following the uncovering of major accounting scams involving large organizations (e.g. Enron), scholars have focussed on managers' motives for engaging in earnings management (Gavious et al., 2012). The literature mentions various factors, for example, debt covenants, pending litigation and the existence of performance-based compensation plans for management, that can motivate earnings management (Jones, 1991). All stakeholders and users of financial information require tools that can moderate managers' tendency to engage in earnings management (Krishnan \& Parsons, 2008).

Several researchers have explored the impact of gender diversity on both financial reporting quality and earnings management (Arun, Almahrog, \& Aribi, 2015; Gavious et al., 2012; Krishnan \& Parsons, 2008; Labelle, Gargouri, \& Francoeur, 2010; Peni \& Vähämaa, 2010; Srinidhi, Gul, \& Tsui, 2011). However, this issue requires further investigation. Equivocal methodologies and inconsistent findings have left researchers and managers perplexed. The main 
cause of this uncertainty is the excessive use of the agency hypothesis, which states that statutory diversity alone is enough to control management and provide motives to defend shareholders' interests (Fama \& Jensen, 1983). Prior studies have also focused on the number or percentage of female directors in examining the relationship between board gender diversity and earnings management. Our study broadens this approach and extends beyond research on gender difference by exploring the channel through which female directors exert influence on earnings management. Following the approach taken by Ben-Amar, Francoeur, Hafsi, and Labelle (2013), we find that statutory diversity has an effect, albeit one that hinges on the individual characteristics or demographic attributes of board members. Statutory diversity is a measure of heterogeneity in the process of board composition, but is of limited influence (Ben-Amar et al., 2013). Demographic diversity (e.g. education, skills and experience) leads to better decisionmaking by nurturing candidness and analytical decision-making among board members (Erhardt, Werbel, \& Shrader, 2003).

Our initial sample consists of companies belonging to the CAC All-Shares index listed on Euronext Paris over the period 2001-2010, during which time appointment of women on boards was voluntary. Indeed, our period ends prior the amendment of the gender quotas law by the French parliament in 2011. This legislation decrees that, from 2014, 20\% of a firm's board members must be women, and that this figure must rise to $40 \%$ from 2016 . In our paper, we employ a carefully formulated methodology for dealing with firm level differences, omitted variables, self-selection bias and endogeneity issues. We use propensity score-matching to match gender-diverse firms and non-gender-diverse firms with very similar characteristics. The analysis serves to determine whether sample firms differ in firm-specific characteristics, regardless of the role of gender diversity. We apply the system GMM regression estimation approach to the matched sample to correct for endogeneity bias. 
Our findings first reveal a negative association between the presence of women on board and the magnitude of earnings management. After statutory and demographic attributes are added to the regression models, the results provide evidence of a positive relationship between female directors and earnings management. This finding suggests that specific attributes of female directors may promote the effective monitoring of earnings management and may also influence the nature of the linkage between the proportion of female directors and earnings management. As regards statutory and demographic attributes, we find that business expertise and audit committee membership are key attributes of women directors for the detection and correction of earnings management. On the other hand, women's leadership and experience are positively related to the level of earnings management. In a supplementary analysis, we also consider the case of women in two top executive positions, namely $\mathrm{CEO}$ and $\mathrm{CFO}$, in relation to earnings quality (Francis, Hasan, Park, \& Wu, 2015; Gavious et al., 2012; Peni \& Vähämaa, 2010). Our findings provide evidence of a negative relation between female executives (CEOs and CFOs) and earnings management, with a more pronounced effect for female CFOs than for female CEOs.

Our paper contributes to the literature on the association between female board directorship and earnings management in two ways. First, we explore the black box relation between gender diversity and firm performance by studying the mediating effect of a large set of female directors' attributes on this relation. Important implications of our findings are that the detection and the correction of earnings management require particular competencies and skills and the decision to appoint women on corporate boards should be based more on their statutory and demographic attributes than on blind implementation of gender quotas. Meanwhile, our recommendations may be still up-to-date after the implementation of the gender quota law since such law remains silent on the requested attributes of the directors. Second, most existing studies are based on AngloAmerican data and cannot be generalized, due to differences in governance and legal structures. 
In this regard, our study adds to the literature by providing empirical evidence on the relation between board gender diversity and earnings management in a French context.

The remainder of our paper proceeds as follows. Section 2 briefly discusses and highlights the value of studying the French institutional background. Section 3 concisely reviews the literature on gender diversity, female specific attributes and the extent of earnings management, and puts forward the hypotheses to be tested. Section 4 describes the data, methodology and variables used in the study. Section 5 presents the study's findings, and the final section contains our closing comments and avenues for future research.

\section{The French institutional background}

The French context is of interest for various reasons. The French civil law-based legal system does not offer adequate investor protection (La Porta, Lopez-de-Silanes, \& Shleifer, 1999). Obviously enough, aggressive earnings management may occur in countries with less protection for minority shareholders, resulting in an environment that is more conducive to weaker financial reporting transparency and where managers enjoy greater discretion (Bushman, Chen, Engel, \& Smith, 2004; Duh, Lee, \& Lin, 2009). Further, as noted by Faccio and Lang (2002), concentration of ownership and the separation of ownership and control are distinctive features of French institutions. These authors report that $70.92 \%$ of non-financially controlled firms are family owned and managed. These controlling family owners exercise control of their firms (Hwang and Kim, 2016) through their associated directors serving on the board (Cuervo, 2002). Furthermore, top managers have close relationships with controlling family owners (Cuervo, 2002; Faccio \& Lang, 2002; Boubaker \& Labégorre, 2008). Concentration of ownership therefore probably decreases the agency problems between controlling shareholders and managers but provides a favourable environment for expropriating minority shareholders (Johnson, La Porta, Silanes, \& Shleifer, 2000). Hence the main issue is to protect minority 
shareholders in a meaningful way from being expropriated by controlling shareholders through earnings management (Chin, Chen, \& Hsieh, 2009; Liu \& Lu, 2007).

The role of the board of directors and of board characteristics (i.e. board independence and gender diversity) is usually associated with the protection of shareholder interests (Gul et al., 2011; Kim, Kitsabunnarat-Chatjuthamard, \& Nofsinger, 2007; Liu \& Lu, 2007; Nekhili \& Gatfaoui; 2013). This role is particularly crucial with regard to the issue of earnings management, in that one of the responsibilities of boards is to monitor management (Klein, 2002; Rahman \& Ali, 2006; Xie, Davidson, \& Dalton, 2003). More closely related to our particular focus, there is considerable evidence to suggest that women are strict monitors of management (Adams \& Ferreira, 2009) and that firms with gender-diverse boards are less likely to manage earnings (Arun et al., 2015; Gavious et al., 2012; Krishnan \& Parsons, 2008; Labelle et al., 2010; Srinidhi et al., 2011). These arguments lead us to explore whether board gender diversity in France has a favourable effect with regard to earnings management.

\section{Background and hypothesis development}

\subsection{Gender diversity and earnings management}

The issue of earnings quality involves monetary and ethical dilemmas, for which existing studies commonly consider gender to be a predicting factor (Krishnan \& Parsons, 2008). Women and men have different capabilities because of differing socialisation processes (Srinidhi et al., 2011). Betz, O’Connell, and Shepard (1989) addresss differences between men and women with regard to monetary and financial matters, and find that women emphasize assisting others, whereas men focus on making money and moving upwards in the organizational hierarchy. Most importantly, women are more ethical in their professional life and less likely than men to act in immoral ways for financial gain (Betz et al., 1989; Kaplan, Pany, Samuels, and Zhang, 2009). In 
addition, Kaplan et al. (2009) suggest that women are more likely to report incidents of fraudulent financial reporting.

Differences in gender characteristics have also been noted in decision-making and risktaking behavior. Prior studies reveal that women are less tolerant of opportunistic behavior when making organizational decisions (Krishnan \& Parsons, 2008) and place less importance on personal interests, appropriateness and common practices. Further, they are more likely to be risk averse than men (Barber \& Odean, 2001; Powell \& Ansic, 1997). Women are more cautious and less aggressive than men in various decision-making contexts (Byrnes, Miller, \& Schafer, 1999), and are less likely to take risks, especially in financial decision-making environments (Powell \& Ansic, 1997). They also tend to act more decisively than men to enhance earnings quality because they are highly sensitive to reputational loss and the risk of lawsuits (Srinidhi et al., 2011). It is therefore generally considered that women will adopt a restrained approach towards earnings management (Gul, Fung, \& Jaggi, 2009).

Krishnan \& Parsons (2008) find that firms with more women in their senior management report high quality earnings. The findings of Srinidhi et al. (2011), echoed by Gavious et al. (2012), also indicate the favourable impact of women directors on earnings quality. A recent study by Arun et al. (2015) shows that firms in the United Kingdom with a majority of female and independent female directors on their boards adopt restrained earnings management practices. However, findings of previous studies do not support this conclusion regarding the relationship between gender diversity and earnings management. For example, Sun, Liu, and Lan (2011) were unable to find any correlation between female participation on audit committees and earnings management. Similarly, Peni and Vahamma (2010) find no relationship between earnings management and the gender of the firm's CEO. In view of the above findings, our first hypothesis is formulated as follows: 


\section{H1. Female directors constrain earnings management.}

\subsection{Statutory diversity of the board and earnings management}

Statutory diversity is essential for effective monitoring of management to protect shareholders' interests (Fama \& Jensen, 1983). Statutory or fiduciary governance focuses on strongly recommended governance practices, for example, the presence of more independent directors on the board and separation of the CEO's and chairperson's roles. This is commonly known as leadership structure (Ben-Amar et al., 2013). Similarly, audit committee independence is generally recognised as a "best practice" for corporate governance. Fiduciary governance is based on the idea that the board's independence from management will improve the overseeing quality of the board, which will indirectly enhance the firm's performance (Fama \& Jensen, 1983; John \& Senbet, 1998). The literature on governance fully explores the propositions of agency theory and suggests that the board's monitoring function is a key element of an organization's governance system (Dalton, Daily, Ellstrand, \& Johnson, 1998; John \& Senbet, 1998). In accordance with the premise of fiduciary governance, statutory diversity is likely to enhance the board's effectiveness, which in turn improves the firm's performance by reducing agency costs (Ben-Amar et al., 2013). Recent studies provide evidence that statutory diversity measures play an active role in ensuring the quality of reported earnings (Arun et al., 2015; Gavious et al., 2012; Srinidhi et al., 2011). To measure the degree to which the board's statutory diversity affects the relation between female directorship and earnings management, we consider three proxies of statutory diversity: women independent directors, audit committee members and women chairs. We further subdivide these variables into two groups based on the monitoring and leadership roles assigned to women directors. 


\subsubsection{Appointment of women to key monitoring positions and earnings management}

The ability of board to oversee management largely depends on key monitoring positions, such as independent directorships and audit committee membership (Fama \& Jensen, 1983; Klein, 2002; Sarbanes Oxley Act, 2002). The primary duty of the audit committee is to monitor the firm's financial reporting process (Klein, 2002; Sarbanes Oxley Act, 2002). Moreover, independent directors exhibit better monitoring skills, which in turn minimizes the likelihood of earnings management and financial fraud (Beasley, 1996; Fama \& Jensen, 1983; Larcker, Richardson, \& Tuna, 2007). The audit committee and board independence are negatively related to earnings management, and boards organized to be more independent are highly effective at monitoring financial reporting process (Klein, 2002).

Diverse boards may also monitor management more effectively, because board independence is associated with board diversity (Adams, Haan, \& Terjesen, 2015). Ferreira (2015) argues that board independence is affected by the gender of directors. The literature provides evidence that gender-diverse boards are more likely to exhibit independent thinking and stronger monitoring ability (Adams \& Ferreira, 2009: Carter, Simkins, \& Simpson, 2003). As regards earnings quality, Bruns and Merchant (1990) emphasize that earnings management poses an ethical dilemma. In this respect, women tend to be better at dealing with ethical issues than men (Krishnan \& Parsons, 2008; Labelle et al., 2010). Empirical support for this proposition is provided by Srinidhi et al. (2011), who find a negative correlation between non-executive female directors and earnings management. In a more recent paper, Arun et al. (2015) argue that firms with a higher proportion of independent female directors tend to adopt restrained earnings management practices.

With regard to board committees, Adams and Ferreira (2009) propose that female directors are more likely than male directors to sit on monitoring-related committees. In particular, women 
are more likely to be found in audit committees. These authors find that the proportion of women on board committees is higher than that of women on boards. Few studies discuss the impact of audit committees' gender diversity on earnings management, but the reported findings are inconsistent. For instance, Gavious et al. (2012) demonstrate that accounting aggressiveness (measured by earnings management) is associated with the proportion of women on audit committees. Firms that have at least one woman in their audit committees produce high quality earnings reports (Srinidhi et al., 2011). Conversely, Sun et al. (2011) find no evidence linking the presence of women on audit committees and earnings management. Thiruvadi and Huang (2011) disagree with the findings of Sun et al. (2011) and suggest that inclusion of female directors on audit committee restrains earnings management. On the basis of the above studies, we put forward the following hypothesis:

H2. The appointment of women directors to key monitoring positions is negatively associated with earnings management.

\subsubsection{Female board leadership and earnings management}

The board chair, alongside other directors, is the highest decision-making level in the organization. The prime duty of the chair is to run the board effectively by promoting the participation of all board members in monitoring the performance of executives and managing board dynamics (Machold, Huse, Minichilli, \& Nordqvist, 2011). The chairperson is expected to lead the board by capturing the value of the diversity of opinions and maintaining coherence among board members in order to bring everyone around to shared organizational goals (Daily \& Dalton, 1997; Machold et al., 2011). All important organizational decisions are made at board meetings, and the chairperson, as a leader for board members, can influence board meetings (Gabrielsson, Huse, \& Minichilli, 2007). Along similar lines, McNulty, Pettigrew, Jobome, and Morris (2009) posit that board chairs use their role and position to influence organizational 
decisions. By focusing on different types of board chairs, they conclude that executive chairs exert more influence on strategy (i.e. decisions about joint ventures, mergers and acquisitions) and resource dependence tasks (creation and distribution of financial, material and symbolic resources), whereas non-executive chairs have more influence over monitoring and control (i.e. hiring, firing and remuneration) of the CEO's and other executives' tasks.

Given that earnings management is an ethical issue (Bruns \& Merchant, 1990), the skills and behaviour of the board chair may be key factors with regard to earnings quality and the quality of financial statements in general. In this regard, the literature in psychology and management has shown that substantial gender differences exist in relation to conservatism, risk aversion, decision-making and leadership style (Kim \& Shim, 2003; Peni \& Vähämaa, 2010). With regard to leadership style, Eagly, Johannesen-Schmidt, and Van Engen (2003) argue that women tend to follow a transformational and democratic or participative leadership style, whereas men are observed to adopt a transactional and autocratic leadership style. The transformational leadership style, which produces less incongruence between the leader role and the gender role (Eagly et al., 2003), is clearly based on ethical, personal and social values to a much greater extent than the transactional leadership style (Hood, 2003). Furthermore, women tend to be less assertive, less overconfident, more legitimate, risk averse and highly ethical (Francis et al., 2015; Ho, Li, Tam, \& Zhang, 2015). These characteristics are suggestive of a conservative mental approach, which is an essential principal of accounting (Francis et al., 2015; Ho et al., 2015), and less likelihood to be involved in fraud (Ho et al., 2015). Another argument is that women are less aggressive decision-makers than men (Francis et al., 2015; Ho et al., 2015; Peni \& Vähämaa, 2010), and more concerned about their reputation. They are therefore inclined to adopt a restrained approach toward earnings management, because they want to avoid the risk of lawsuits and loss of reputation (Gul et al., 2009; Srinidhi et al., 2011). By focusing on women's distinctive traits, such as accounting conservatisim, risk aversion, firm opposition to fraud, higher ethical standards, 
reputational concerns (e.g. Francis et al., 2015; Ho et al., 2015; Peni \& Vahama, 2010) and adoption of the transformational leadership style appropriate for the chairperson, we suggest that female leaders are more suited to the chair position with regard to the assessment of earnings management. Therefore, we propose the following hypothesis:

H3. Women chairs are likely to decrease the level of earnings management.

\subsection{Demographic diversity of corporate boards and earnings management}

Demographic diversity is likely to have a direct effect on the board's decision-making ability by raising the level of directors' skills and competencies (Ben-Amar et al., 2013). From the standpoint of human capital theory, people's demographic attributes (e.g. education, skills and experience) can enhance their cognitive and productive abilities, which benefits both the individual and his/her organization (Becker, 1964). As regards board membership, Kesner (1988) asserts that in order to be considered for directorships, individuals should have a wide range of human capital and demographic attributes. Similarly, in the French context, Nekhili and Gatfaoui (2013) suggest that women are hired by boards on the basis of their demographic characteristics. Therefore, boards tend to appoint women if they possess specific demographic attributes (e.g. behaviour, education background and experience) to a greater than men.

The study by Labelle et al. (2010) argues that diversity other than required by the standards and codes of corporate governance is likely to be part of governance practices for the defence of stakeholders' interests. Diversity that is not required by corporate governance standards is demographic in nature (education, business expertise and experience). Furthermore, Carter et al. (2003) contend that agency theory (statutory differences among board members) is not enough to guarantee a real relationship between board diversity and organizational performance. Statutory diversity has an effect, but it depends upon the individual characteristics or demographic attributes of board members (Ben-Amar et al., 2013). In the context of this study, we also expect 
a similar effect from the demographic diversity of female board members. Demographic diversity of female board members is likely to complement statutory diversity, which is expected to improve the monitoring function of the board for decreasing earnings management by managers. Studies on diversity mostly take into account the effect of one element of demographic diversity at a time (Ben-Amar et al., 2013). Contrary to existing studies, we consider the effect of women's education level, business expertise, nationality, tenure and multiple directorships. We further categorize these attributes into two groups on the basis of women directors' educational expertise (education level and background) and experience (tenure, multiple directorships and nationality).

\subsubsection{Educational expertise of women directors and earnings management}

Individuals with and without business education tend to exhibit different decision-making styles (Hambrick \& Mason, 1984; O’Fallon \& Butterfield, 2005). In a recent paper, Nekhili and Gatfaoui (2013) propose that women directors need to have business education and expertise to reach key positions (e.g. membership of various board committees) in the organization. Moreover, financial expertise of audit committee members is an important factor for ensuring the quality of reported earnings (Bédard \& Gendron, 2010). However, irrespective of all other traits, business expertise (such as an MBA) can enhance an individual's chances of success and appointment to the board in today's complex business environment (Ruigrok, Peck, \& Tacheva, 2007).

With regard to education level, Papadakis and Barwise (2002) suggest that highly educated individuals are able to make better decisions because of their cognitive ability to process and analyse available information. For managing boardroom diversity, it is important to consider directors' qualifications (education level and background) (Ruigrok et al., 2007). Daily and Dalton (1994) point out that most women directors have a business education background. These studies provide evidence that irrespective of background (business or non-business); education 
level can enhance an individual's chances of success and appointment to a board of directors. We therefore anticipate that educational expertise ${ }^{1}$ of women directors will decrease the magnitude of earnings management. Hence, the following hypothesis is tested:

H4. Educational expertise of women directors is likely to restrain earnings management.

\subsubsection{Experience of women directors and earnings management}

Experience and familiarity with business enhance the competencies of individuals' contribution to the complex and highly sensitive proceedings of boards (Kesner, 1988). The experience and expertise of outside directors strengthen their advisory abilities and are likely to improve the quality of their strategic decision-making (Kroll, Walters, \& Wright, 2008; McDonald, Westphal, \& Graebner, 2008). Most importantly, firms should hire and retain outside directors whose experience matches their strategic plans (McDonald et al., 2008). Various writers conclude that by acquiring experience, directors improve their advisory skills, which in turn will improve the decision-making ability of the board (Kroll et al., 2008; McDonald et al., 2008). In the context of this study, we consider three proxies of experience - tenure, multiple directorships and nationality of women directors - commonly used in the literature.

Organizational demographic research shows that a director's tenure has a strong impact on the firm's performance (Kosnik, 1990). One study found that it takes directors three to five years to gain an adequate understanding of a firm and the way it operates (Bacon \& Brown, 1973), and that a detailed understanding of the firm requires longer (Kesner, 1988). As regards financial reporting, Beasley (1996) argues that chances of financial statement fraud decrease as the tenure of outside directors increases. Similarly, Bédard, Chtourou, and Courteau (2004) conclude that the level of earnings management (abnormal accruals) is inversely associated with the average tenure of outside committee members.

\footnotetext{
${ }^{1}$ The term "educational expertise" is used interchangeably with the terms education level and background of women directors.
} 
Holding multiple board seats enables directors to build a reputation as monitoring experts (Fama \& Jensen, 1983). The literature provides strong support for the positive reputation effect of multiple directorships - measured by the number of board seats held by independent directors in several corporate governance scenarios (Vafeas, 1999). Multiple directorships can facilitate the exchange of information, and such information may be vital for organizations to find and assess evolving opportunities (Connelly \& Van Slyke, 2012). Indeed, multiple directorships enhance the level of an individual's understanding of the business environment and organizational issues, which in turn improves directors' monitoring efficiency (Connelly \& Van Slyke, 2012; Fama \& Jensen, 1983; Vafeas, 1999). More recently, Shu, Yeh, Chiu, and Yang (2015) suggest that externally connected directors thereby gain financial expertise, which helps them to reduce the level of earnings management.

In contrast with the above studies, another stream in the literature proposes that multiple directorships can be detrimental for organizations and results in weaker corporate governance, poor financial performance and lower market-to-book ratios (Cashman, Gillan, \& Jun, 2012; Fich \& Shivdasani, 2006). These effects might stem from inefficient monitoring of management by "over-boarded" directors, due to less time available for considering in detail the managerial issues of all the firms (Lipton \& Lorsch, 1992). Furthermore, the probability of financial fraud increases in proportion to the average number of multiple board seats held by independent directors (Beasley, 1996). Finally, the contagion effect hypothesis suggests that earnings management is a virus that spreads from one organization to another through multiple directorships (Chiu, Teoh, \& Tian, 2013). According to the busyness hypothesis, contagion effect hypothesis, and the learning effect hypothesis, multiple directorships can be value detrimental or incremental for organizations.

From the perspective of resource dependence theory, the cultural knowledge and know-how of foreign directors are valuable for firms in those directors' domestic market (Ruigrok et al., 
2007). Consistently with resource dependence theory, we consider foreign female directors as a proxy of international experience. In a previous study of foreign directors, Choi, Park, and Yoo (2007) reported the positive impact of foreign board members on firm performance. Similarly, Oxelheim and Randøy (2003) conclude that Norwegian and Swedish firms with foreign directors on their boards have higher valuations than their competitors without foreign independent directors. In the context of this study, foreign women directors are expected to have a positive impact on the quality of reported earnings. Taken together, these studies suggest that all proxies of experience - tenure, multiple directorships and nationality - enhance the monitoring ability of the board, which is likely to reduce the chances of earnings manipulation by managers. Hence, we propose the following hypothesis:

H5. Women directors' experience is negatively associated with earnings management.

\section{Data and methodology}

\subsection{Data selection}

Our initial sample comprises companies listed on the Euronext Paris CAC All-hares Index with a trading volume higher than $5 \%$ of their share capital, irrespective of market capitalization, during the period 2001-2010. The sample starts in 2001 due to the non-availability of governance data in earlier periods and ends in 2010, in order to consider female directors appointed on a totally voluntary basis. ${ }^{2}$ We exclude real estate, foreign, and financial firms from the initial sample due to their different regulations. After applying the data restrictions above, our final sample comprises 394 firms in the 2001-2010 period, for a total of 3160 unbalanced firm-year observations. Accounting and financial data were collected from Thomson Datastream. The

\footnotetext{
${ }^{2}$ As highlighted by Singh, Point, Moulin, and Davila (2015), French companies had then only three years to comply with the 2011 quota legislation (i.e., from 2014, 20\% of a firm's board members must be women). As a result, the number of female directors started to grow considerably from 2011. In the view of these authors, this urgency leads to questions about the supply and legitimacy of the women who had been appointed in the period between the implementation in 2011 and the application of the quota law (20\% from 2014 and 40\% from 2016).
} 
Thomson One database was utilised to collect information about ownership structure. Data regarding governance variables, women directors and their specific attributes were collected from annual reports and cross-checked with information available on www.whoswho.fr and www.dirigeant.societe.com.

\subsection{Measure of earnings management}

Prominent scholars suggest that managers use accruals mostly to manipulate earnings, because accruals are hard to detect by external stakeholders (Dechow, Sloan, \& Sweeney, 1995; Jones, 1991; Kothari, Leone, \& Wasley, 2005). Furthermore, earnings can be managed through short or long-term discretionary accruals (Arun et al., 2015). Becker, DeFond, Jiambalvo, and Subramanyam (1998) suggest that managers have more discretion over short-term or current accruals than over long-term accruals. In this study, we gauge earnings management (i.e. current discretionary accruals) using the Modified Jones Model (Dechow et al., 1995), ${ }^{3}$ which is widely used to measure current discretionary accruals (Arun et al., 2015; Gavious et al., 2012; Park \& Shin, 2004; Shu et al., 2015). Following Dechow et al. (1995), we estimate current accruals by using the cross-sectional regression equation below: ${ }^{4}$

$$
\mathrm{CA}_{\mathrm{it}} / \mathrm{A}_{\mathrm{it}-1}=\beta_{\mathrm{it}}\left[1 / \mathrm{A}_{\mathrm{it}-1}\right]+\beta_{\mathrm{it}}\left[\left(\Delta \mathrm{SALES}_{\mathrm{it}}-\Delta \mathrm{TR} \mathrm{R}_{\mathrm{it}}\right) / \mathrm{A}_{\mathrm{it}-1}\right]+\varepsilon_{i t}
$$

where $\mathrm{CA}_{\mathrm{it}}$ are current accruals, measured as net income before extraordinary items minus operating cash flow, $\mathrm{A}_{\mathrm{it}-1}$ denotes total assets at the beginning of each year, $\triangle \mathrm{SALES}_{\text {it }}$ is the

\footnotetext{
${ }^{3}$ Jones (1991) relates total accruals to the change in sales ( $\triangle$ SALES) and gross property plant and equipment (PPP) as given below:

$$
\mathrm{TA}_{\mathrm{it}} / \mathrm{A}_{\mathrm{it}-1}=\alpha_{1}\left[1 / \mathrm{A}_{\mathrm{it}-1}\right]+\alpha_{2}\left(\triangle \mathrm{SALES}_{\mathrm{it}} / \mathrm{A}_{\mathrm{it}-1}\right)+\alpha_{3}\left(\mathrm{PPT}_{\mathrm{it}} / \mathrm{A}_{\mathrm{it}-1}\right)
$$

Sales are subject to earnings management by managers (i.e. increasing the sales recognition by the end of year). By using the Jones Model, we remove the portion of discretionary accruals (Arun et al., 2015). Due to this limitation of the Jones Model, we follow the modified version of the Jones Model developed by Dechow et al., (1995).

${ }^{4}$ Consistently with the studies of Arun et al. (2015) and Park and Shin (2004), industry groups with fewer than six observations are excluded from the sample.
} 
change in sales, and $\Delta \mathrm{TR}_{\mathrm{it}}$ is the change in trade receivables. The residual $\left(\varepsilon_{i t}\right)$ of the equation is current discretionary accruals $(C D A)$. The subscripts i and t stand for firm and year.

\subsection{Control variables}

In our study, firm-specific characteristics that can influence the level of accruals and gender diversity are considered. Board size $\left(B \_S I Z E\right)$ is the number of directors on a board. There is disagreement in the literature regarding the effect of board size on earnings management. Xie et al. (2003) find a negative correlation between board size and earnings management. Conversely, Rahman and Ali (2006) suggest a positive relationship between the two. Prior studies support the idea that board independence $\left(B \_I N D\right)$ can reduce earnings management (Beasley, 1996; Klein, 2002). Board meetings ( $B \_M E E T$ ) represent the degree of board activity and are therefore expected to decrease the level of earnings management (Xie et al., 2003). Similarly to Ahn, Jiraporn, and Kim (2010), we control for CEO duality (DUAL) to measure CEO entrenchment. In line with the study by Gavious et al. (2012) a positive impact of CEO duality (DUAL) on earnings management is expected. Davidson, Xie, Xu, and Ning (2007) assert that CEOs who are approaching retirement age are more prone to manage earnings through accruals. In light of this finding, it is interesting to study the influence of CEO tenure (CEO_TEN) on earnings management. Family ownership $\left(F A M_{-} O W N\right)$ is the percentage of shares held by families. With regard to family ownership (FAM_OWN), Jaggi and Leung (2007) state that concentration of ownership in the hands of families is conducive to discouraging earnings management. Similarly, institutional ownership (INST_OWN) limits the management's ability to manipulate earnings (Koh, 2003; Park \& Shin, 2004). To control for audit quality, we use the variable “ $B I G$ " because the presence of a big audit firm is associated with higher earnings quality (Gavious et al., 2012). Leverage and loss are proxies for the firm's financial condition. To date, empirical findings for the impact of leverage ( $L E V)$ on earnings management are inconclusive (Vasilescu \& Millo, 
2016). Several studies indicate that managers in financially distressed firms exert less discretion over accruals estimates (Arun et al., 2015; Gavious et al., 2012; Srinidhi et al., 2011). Consequently, we expect a negative relationship between financial loss (LOSS) and earnings management. Tobin's $\mathrm{Q}(T Q)$ is used as a proxy for the firm's financial performance. Similarly to Shu et al. (2015), a negative relationship is expected between Tobin's Q and earnings management. The research and development $(R \& D)$ intensity of firms may affect earnings management. With respect to operating cash flow $(C A S H)$, Gul et al. (2009) report that firms with a higher level of operating cash flows are less likely to engage in earnings manipulation. We consider foreign assets (FOR_ASSETS) of sample firms to account for the effect of foreign investment on the level of earnings management. Systematic risk is measured by BETA; firms at high risk will exert more discretion on earnings to reduce perceived risk. Following Labelle et al. (2010), we expect a positive association between market risk and earnings management. We also control for U.S. cross-listing (CROSS), following Lang, Raedy, and Wilson (2006), who find evidence of earnings management in cross-listed firms. Finally, firm size (F_SIZE), measured by the natural logarithm of total assets, is expected to have a negative relationship with earnings management (Peni \& Vähämaa, 2010; Shu et al., 2015). Given that the extent of earnings management may differ over time and by industry, we also add dummies to control for the possible effect of time and industry. Table 1 describes all variables considered in our study.

[Please insert Table 1 here]

\section{Data analysis and results}

\subsection{Descriptive statistics}

Table 2 (Panel A) presents descriptive statistics for our sample firms. The average value of current discretionary accruals $(C D A)$ measured by the Modified Jones Model (MJM) is 0.012 , indicating that on average French firms are involved in income-increasing earnings management. 
With regard to women directors (WDIR_BIN \& WDIR_NB), we find that on average sample firms have fewer than one female director on their boards. On these boards, the mean percentage of women (WDIR_\%) is 10.72 , and $4.62 \%$ of chairpersons are female (WCHAIR). The mean of independent women directors (WIND) is $8.9 \%$, and the proportion of women directors on audit committees (WACOM) is only $2.37 \%$. Note that $46.82 \%$ of women directors are highly educated (WEDUC) and that $45.82 \%$ come from a relevant business education background (WBUS). Approximately $9 \%$ of women directors are foreign nationals (WNAT). As for experience, the majority (61.6\%) of women directors hold multiple directorships (WMUL), and the average tenure of women directors (WTEN) is 6.51 years. In our sample, the mean percentage of female CEOs (WCEO) and CFOs (WCFO) is 3.63\% and 12.99\% respectively. Panel A of Table 2 also provides descriptive statistics for control variables. Average boards (B_SIZE) have 7.7 directors. $27.54 \%$ of whom are independent $\left(B \_I N D\right)$. The average number of board meetings $\left(B \_M E E T\right)$ is 6.36 per year, and in $62.58 \%$ of the firm-years there is CEO/Chairperson duality (DUAL). The average tenure of chief executive officers $\left(C E O \_T E N\right)$ is 7.82 years. We also find that on average $36.84 \%$ of shares are held by family owners and that institutional shareholding is $18 \%$. These statistics reveal that families hold more shares than institutions. The median number of big auditors $(B I G)$ is 1 across our sample firms. The mean of financial leverage ( $L E V)$ is $23.10 \%$ and Tobin's Q (TQ) is slightly higher than unity (1.041). Almost $24 \%$ of firms report incidents of financial loss $(L O S S)$ in their financial statements. The R\&D intensity $(R \& D)$ is $1.81 \%$ on average and the mean of operating cash flow is $9.88 \%$. Our sample firms invest $18.77 \%$ of their assets in foreign countries (FOR_ASSETS) and their systematic risk (BETA) is less than unity (0.658). Some $8.6 \%$ of the firms are cross-listed (CROSS) in the United States, and average firm size (F_SIZE) is 4.919 billion euros. These statistics are similar to those of prior studies conducted on French corporations (e.g. Nekhili \& Gatfaoui, 2013). 
Panel B of Table 2 presents the summary statistics regarding the proportion of women directors across our sample firm-years. These statistics show that in 1629 (51.53\%) firm-years, our sample firms have no women on their boards. In 1053 (33.2\%) firm-years, only one woman is present on these boards. In 357 (11.30\%) firm-years, two female directors have been appointed to the board. These statistics reveal that fewer than half $(48.47 \%)$ of our sample firms have gender-diverse boards. In addition, $33.32 \%, 11.30 \%, 2.56 \%$ and $1.27 \%$ of sample firm-years have 1, 2, 3 and 4 female directors on their boards, respectively. The majority (33.2\%) of our sample's gender-diverse firms have only one woman on their boards, and there are very few firms with more than one woman on the board. For these reasons, we consider three different measures of women directorship - a dummy variable, and the percentage and number of women directors - commonly used by researchers (Arun et al., 2015; Gavious et al., 2012; Srinidhi et al., 2011).

[Please insert Table 2 here]

Table 3 exhibits descriptive statistics by year for the percentage of women directors, the number of women directors, women directors' attributes and the percentage of women in top executive positions (i.e., $\mathrm{CEO}$ and $\mathrm{CFO}$ ). The results clearly indicate that while the percentage and the number of women directors increased significantly over the years, the number of women at top management levels (WCHAIR, WCEO and WCFO) did not. Nekhili, Chakroun, and Chtioui (2016) claim that this phenomenon is global and firms tend, almost everywhere in the world, to respond to pressure from different stakeholders by promoting gender diversity on boards. Nevertheless, the access of women to the highest levels of management continues to be extremely limited (Nekhili et al., 2016). For the other attributes evolved over time, we note the presence of more independent women directors on French boards. They are also more likely to have a business degree and more prone to access to the audit committee. Finally, they are on 
average more experienced as captured by tenure. No significant changes are observed over the years for the rest of women directors' attributes such as education, nationality and multidirectorship. These trends may reflect a wider cultural shift in French companies towards board gender diversity as well as the attributes required for female directorship candidates.

[Please insert Table 3 here]

\subsection{Propensity score matching}

The possible effect of gender diversity may be due to firm-related factors that affect gender diversity and earnings management simultaneously. In this scenario, direct analysis of all firms is not appropriate due to differences in firm-level characteristics. To eliminate differences in firmspecific factors, we use propensity score matching, as in Rosenbaum and Rubin (1983). We match gender-diverse firms (with one female director) in a meaningful way with a set of control firms (with all-male boards) having almost identical characteristics (the nearest predicted propensity score) to gender-diverse firms. Bad matching occurs if the nearest neighbour is distant. Using a calliper distance of $1 \%$ without replacement, ${ }^{5}$ we impose a restriction on the maximum propensity score (calliper) so as to reduce the probability of bad matching. Propensity score matching yields a matched sample consisting of 1894 cases: 947 treatment (firms with gender-diverse boards) and 947 control cases (firms with all-male boards). Table 4 shows that post-match pairwise differences of the control variables decrease in magnitude with respect to the pre-match sample and become statistically insignificant. Comparing the results of the entire sample to those of the matched sample, we find no significant difference in firm-specific characteristics between gender-diverse and non-gender-diverse firms.

[Please insert Table 4 here]

\footnotetext{
${ }^{5}$ Matching without replacement means that the same gender-diverse firm can be matched to only one non-genderdiverse firm.
} 
In Table 5, we report the findings of the Pearson correlation analysis and variance inflation factors (VIF) for dependent, independent and control variables. The correlation among all variables is below 0.5 and variance inflation factors (VIF) are also less than the critical value of 10, as suggested by (O'Brien, 2007). There is therefore no multicollinearity issue that might influence our results.

[Please insert Table 5 here]

\subsection{Principal component analysis (PCA)}

Principal component analysis (PCA) is a statistical tool used to summarise large amounts of data in comparatively few "components", which specifies the maximum possible variation from the original variables, in order to make interpretations more understandable (Abdi \& Williams, 2010). The variance of each component is the eigenvalue of that particular component, while the component loadings matrix is the correlation among the original variables and derived components. Kaiser's rule suggests retaining only those components with eigenvalues greater than unity. We can use PCA only if there is sufficient correlation between the original variables. A commonly used measure for sampling adequacy is Kaiser-Meyer-Olkin (KMO), which assumes values between 0 and 1. Low values are an indication of low correlation. A KMO value of higher than 0.5 is considered satisfactory to justify the use of PCA.

Initially we included eight variables on the statutory and demographic attributes of women directors in our study. To make interpretations more meaningful, we chose to reduce the variables by means of PCA. We applied the KMO measure of sample adequacy to justify the use of PCA. The KMO test in PCA using eight original attributes shows that the KMO index is higher than 0.5 (0.72), with significance equal to 0 . We obtained eight components with calculated eigenvalues corresponding to eight original variables. However, only four components with eigenvalues more than unity were retained for further analysis. 
Table 6 presents the four derived components with their "names" and loadings. These derived components are named after the variables with which they are highly correlated. The first component has the highest correlation (0.531) with business education (WBUS), meaning that the first component is explained by the variable business education. Therefore the first component is named "EXPERTISE." The second component is named "LEADERSHIP" because it loads highly (0.671) on women chairpersons (WCHAIR), which is a proxy of leadership. Similarly, the third component ranks high on both proxies of experience: multiple directorships $(0.622)$ and tenure of women directors (0.548). Accordingly, the third component is named "EXPERIENCE." Finally, the fourth component loads heavily (0.660) on women directors' audit committee membership, and is named committee membership (AUDCOM_MEMB). The remaining attributes that loaded on these components are given in Table 6. In total, these four retained components account for $60.6 \%$ of the variance in the original attributes. Scholars suggest that a component analysis that explains $60 \%$ of the variance in the original variables is satisfactory (Carcello, Hermanson, \& McGrath, 1992). For further analysis, these four components are used as endogenous variables in our model to investigate the effect of women directors and their specific attributes (statutory and demographic) on the extent of earnings management.

\section{[Please insert Table 6 here]}

\subsection{Test of $\mathrm{H1}$}

Our study considers that both gender diversity and earnings management are endogenous. In this scenario, the potential effect of gender diversity may be driven by certain firm-specific characteristics simultaneously affecting gender diversity and earnings management. This is the classical endogeneity effect. Following Blundell and Bond (1998), to control for the possible endogeneity effect, we use the two-step General Method of Moments (GMM) estimation 
approach to capture the relationship between gender diversity and earnings management. This method is commonly known as the system GMM. ${ }^{6}$

$$
\begin{aligned}
& C D A_{i, t}=\alpha_{0}+\alpha_{1} \operatorname{Lag} C D A_{i, t}+\alpha_{2} W D I R_{i, t}+\alpha_{3} B_{-} S I Z E_{i, t}+\alpha_{4} B_{-} I N D_{i, t}+\alpha_{5} B_{-} M E E T_{i, t}+ \\
& \alpha_{6} D U A L_{i, t}+\alpha_{7} C E O_{-} T E N_{i, t}+\alpha_{8} F A M_{-} O W N_{i, t}+\alpha_{9} I N S T_{-} O W N_{i, t}+\alpha_{10} B I G_{i, t}+\alpha_{11} L E V_{i, t}+ \\
& \alpha_{12} T Q_{i, t}+\alpha_{13} \text { LOSS }_{i, t}+\alpha_{14} R \& D_{i, t}+\alpha_{15} \text { CASH }_{i, t}+\alpha_{16} \text { FOR_ASSETS }_{i, t}+\alpha_{17} \text { BETA }_{i, t}+ \\
& \alpha_{18} \text { CROSS }_{i, t}+\alpha_{19} F_{-} S I Z E_{i, t}+I_{N D U S T R Y \_} F E+Y E A R_{-} F E+\varepsilon_{i t}
\end{aligned}
$$

where $\varepsilon_{\mathrm{it}}$ is the error term and the subscripts $i$ and $t$ stand for industry and year respectively.

Table 7 presents the results of the system GMM regression for the matched sample in order to examine whether there is a relation between women directorship (our proxy for gender diversity) and current discretionary accruals (our proxy for earnings management). Here the main variable of interest is women directorship. In Model 1, we consider the presence (or not) of at least one female director (WDIR_BIN), and in the two other Models ( $2 \& 3)$, we consider the percentage of women directors to total directors (WDIR_ \%) and the number of women directors $\left(W D I R \_N B\right)$ respectively.

As proposed in hypothesis $\mathrm{H} 1$, results in Table 7 show a negative and significant relationship between women directorship and current discretionary accruals in all models. This result is in line with our expectation that firms with gender-diverse boards exhibit higher monitoring skills and decrease the level of earnings management (Arun et al., 2015; Gavious et al., 2012; Krishnan \& Parsons, 2008; Srinidhi et al., 2011) in order to protect minority shareholders from being abused through earnings management by managers and controlling shareholders.

[Please insert Table 7 here]

\footnotetext{
${ }^{6}$ The standard GMM considers only the first difference of each variable in a regression, while the lagged levels of explanatory variables are used as instruments. Blundell and Bond (1998) introduce the levels equation into the estimation procedure to produce a system GMM of two equations involving both the levels equation itself and the first-differenced equation.
} 


\subsection{Test of $\mathrm{H} 2$ to $\mathrm{H} 5$}

Table 8 presents the results of three different models that predict the effect of women directorship and their specific (statutory and demographic) attributes on the extent of earnings management measured by current discretionary accruals. In Model 1, we study the relationship between specific (statutory and demographic) attributes of female directors and current discretionary accruals on firms that have at least one woman on their boards, using four components derived through PCA instead of the original variables. In Models 2 and 3, we investigate the impact of board gender diversity on the extent of earnings management by considering the combined effect of female directors and their specific (statutory and demographic) attributes. In these models, women directorship is measured as the percentage of women directors to total directors $\left(W D I R_{-} \%\right)$ and the number of women directors (WDIR_NB) respectively.

$$
\begin{aligned}
& C D A_{i, t}=\alpha_{0}+\alpha_{1} \operatorname{LagCDA}_{i, t}+\alpha_{2} \text { WDIR }_{i, t}+\alpha_{3} \text { COM_MEMB }_{i, t}+\alpha_{4} L E A D E R S H I P_{i, t}+
\end{aligned}
$$

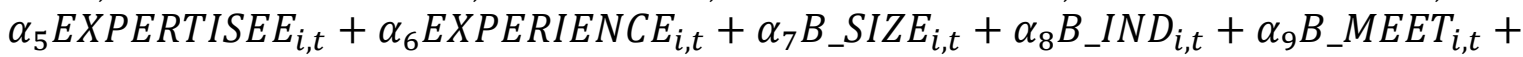

$$
\begin{aligned}
& \alpha_{10} D U A L_{i, t}+\alpha_{11} C E O_{-} T E N_{i, t}+\alpha_{12} F A M_{-} O W N_{i, t}+\alpha_{13} I N S T_{-} O W N_{i, t}+\alpha_{14} B I G_{i, t}+ \\
& \alpha_{15} L E V_{i, t}+\alpha_{16} T Q_{i, t}+\alpha_{17} L_{O S S} S_{i, t}+\alpha_{18} R \& D_{i, t}+\alpha_{19} C_{A S H_{i, t}}+\alpha_{20} F_{\text {FOR_ASSETS }}+ \\
& \alpha_{21} \text { BETA }_{i, t}+\alpha_{22} \text { CROSS }_{i, t}+\alpha_{23} F_{-} S I Z E_{i, t}+\text { INDUSTRY_FE }+ \text { YEAR_FE }+\varepsilon_{i t}
\end{aligned}
$$

where $\varepsilon_{\mathrm{it}}$ is the error term and the subscripts $i$ and $t$ stand for industry and year respectively

The key finding is that results of Models 2 and 3 provide evidence of a significant and positive link between women directorship (WDIR) and current discretionary accruals $(C D A)$, our proxy of earnings management. These results show that the negative effect of women directorship on the extent of earnings management observed in Table 7 is not due solely to the presence of female directors on the board. In fact, the negative impact of women directorship on earnings management was due to their specific (statutory and demographic) attributes. The addition of specific attributes in regression models meaningfully changes the nature of the association between women directors and earnings management. 
In accordance with $\mathrm{H} 2$, we find a negative relationship between audit committee membership $\left(C O M \_M E M B\right)$ of women directors and the level of discretionary accruals. Prior studies also show that the appointment of women directors to audit committee can minimize incidents of earnings manipulation (Gavious et al., 2012; Srinidhi et al., 2011; Thiruvadi \& Huang, 2011). In line with these studies, our findings suggest that the presence of women on audit committee leads to successfully tackling the problem of earnings management. The positive linkage proposed by Adams and Ferreira (2009) and Carter et al. (2003) between gender diversity and monitoring ability of the board seems also to apply to audit committees.

Regarding female leadership, we find that women chairs have a positive and statistically significant impact on current discretionary accruals. A possible reason for this is that the argument of greater board effectiveness in monitoring management in the financial reporting process as a result having a woman as the board chairperson does not hold. The authority of chairpersons is derived from the firm's board of directors, in that they do not have discretion over the decision-making process and make decisions subject to the consent of the entire board of directors (Gabrielsson et al., 2007). Our results thus call into question the capacity of female chairpersons in obtaining the agreement of all board members to influence organizational decisions and to monitor the performance of executives. Hence, $\mathrm{H} 3$ is not supported by our results.

Consistently with hypothesis H4, we find that women directors' business education and expertise is an important attribute for curbing earnings management. The impact of business expertise on current discretionary accruals is negative and significant at the $1 \%$ level. Women directors with a business educational background and financial expertise are therefore more likely to reduce the tendency of managers to manipulate earnings. This result corroborates the findings of Nekhili and Gatfaoui (2013) that business expertise is the most important attribute of women directors. Finally, in line with prior studies (Bédard \& Gendron, 2010; Park \& Shin, 2004), we 
show that business education and financial expertise of women directors is an important attribute for effective monitoring of earnings management.

Contrary to hypothesis H5, our results show that experience has a positive effect on the magnitude of current discretionary accruals. This result is in accordance with the hypothesis of busyness and the contagion effect. In support of the busyness hypothesis, Ahn et al. (2010) and Lipton and Lorsch (1992) argue that multiple directorships reduce the monitoring quality of the board, because directors with multiple board seats have less time available to consider in detail the managerial issues of all firms (Fich \& Shivdasani, 2006). With reference to the hypothesized contagion effect, Chiu, Teoh, and Tian (2013) propose that earnings management is a virus that spreads from one organization to another through multiple directorships. With regard to tenure, Xie et al. (2003) also find that the tenure of independent directors and the level of current discretionary accruals are positively associated. We therefore reject hypothesis H5.

With regard to control variables, we observe a dual relationship between board size (B_SIZE) and current discretionary accruals. Therefore no major conclusion can be drawn. In line with Klein (2002), we find that board independence $\left(B \_I N D\right)$ is negatively associated with the level of discretionary accruals. The number of board meetings $\left(B \_M E E T\right)$ has a negative impact on our proxy of earnings management. The number of board meetings indicates the degree of board activity and this is expected to reduce the magnitude of earnings management (Xie et al., 2003). In line with our expectations, CEO duality (DUAL) encourages the practice of earnings management (Gavious et al., 2012), whereas CEO tenure (CEO_TEN) is negatively associated with earnings management as measured by current discretionary accruals. This latter finding contradicts the study by Davidson et al. (2007) which asserts that CEOs near retirement are more likely to engage in earnings manipulation. As regards ownership structure, we find both family and institutional shareholdings have a negative effect on the level of earnings management. These 
findings are in accordance with those of prior studies (Jaggi \& Leung, 2007; Koh, 2003; Park \& Shin, 2004).

For the remaining control variables, we find that the choice of big auditing firms $(B I G)$ increases the level of earnings management. In support of this finding, Francis and Wang (2008) state that earnings quality will be high for firms audited by the Big 4 auditors in regimes with strong investor protection. Given the greater sanctions in countries with strong minority protection, auditor incentives change and big auditing firms are more likely to enforce higher earnings quality as investor protection regimes become stronger. Similar to the findings of Arun et al. (2015), leverage ( $L E V$ ) exerts a negative effect on the level of current discretionary accruals. The proxy of the firm's financial performance, Tobin's $\mathrm{Q}(T Q)$, is negatively linked to earnings management. The variable "loss" has a negative and highly significant correlation with the extent of earnings management as measured by $C D A$, showing that managers in less profitable firms are less likely to engage in earnings management (Srinidhi et al., 2011). The intensity of $\mathrm{R} \& \mathrm{D}(R \& D)$ is positively related to current discretionary accruals, albeit insignificant in Model 1 and Model 2. In line with Gul et al. (2009), we find that the higher the level of operating cash flows $(\mathrm{CASH})$, the lower the magnitude of earnings management. In accordance with Chin et al.(2009), we find that firms with offshore investments (FOR_ASSETS) exhibit higher level of earnings management as measured by discretionary accruals. In contrast to the study by Labelle et al. (2010), our results suggest that market risk measured by beta minimizes the chances of earnings manipulation. Like Lang et al. (2006), we find that cross-listed (CROSS) firms are more likely to manipulate earnings through current discretionary accruals. This result is consistent with the "avoiding" hypothesis put forward by Licht (2003), in which he posits that corporate governance is a second-order factor in the U.S. cross-listing decision and that foreign firms are more likely to avoid more stringent regulations. Our findings are mixed with regard to firm size. From one model to another, the impact of firm size on $C D A$ varies considerably. 
[Please insert Table 8 here]

\subsection{Supplementary analysis}

Due to the involvement of executives in the financial reporting process and accounting related decision-making, female top executives, specifically CEOs and CFOs, may also affect the degree of earnings management (Francis et al., 2015; Jiang, Petroni, \& Wang, 2010). The main argument is that female CFOs/CEOs tend to be more conservative than men in their financial reporting, due to their risk-averse approach (Francis et al., 2015; Ho et al., 2015). As a robustness check, we add variables, i.e. female $\mathrm{CEO}$ and $\mathrm{CFO}$, to the regression analysis to check whether our results are consistent when women hold executive (CEO \& CFO) positions. ${ }^{7}$

$$
\begin{aligned}
& C D A_{i, t}=\alpha_{0}+\alpha_{1} L_{a g C D A_{i, t}}+\alpha_{2} W D I R_{i, t}+\alpha_{3} \text { COM_MEMB }_{i, t}+\alpha_{4} L E A D E R S H I P_{i, t}+ \\
& \alpha_{5} \text { EXPERTISEE }_{i, t}+\alpha_{6} \text { EXPERIENCE }_{i, t}+\alpha_{7} W_{\text {CEO }}{ }_{i, t}+\alpha_{8} W_{C F O} O_{i, t}+\alpha_{9} B_{-} S I Z E_{i, t}+ \\
& \alpha_{10} B_{-} I N D_{i, t}+\alpha_{11} B_{-} M E E T_{i, t}+\alpha_{12} D U A L_{i, t}+\alpha_{13} C E O_{-} T E N_{i, t}+\alpha_{14} F A M_{-} O W N_{i, t}+ \\
& \alpha_{15} I N S T_{-} O W N_{i, t}+\alpha_{16} B I G_{i, t}+\alpha_{17} L E V_{i, t}+\alpha_{18} T Q_{i, t}+\alpha_{19} L O S S_{i, t}+\alpha_{20} R \& D_{i, t}+ \\
& \alpha_{21} \text { CASH }_{i, t}+\alpha_{22} \text { FOR_ASSETS }_{i, t}+\alpha_{23} \text { BETA }_{i, t}+\alpha_{24} \text { CROSS }_{i, t}+\alpha_{25} F_{-} \text {SIZE }_{i, t}+ \\
& \text { INDUSTRY_FE }+Y E A R_{-} F E+\varepsilon_{i t}
\end{aligned}
$$

where $\varepsilon_{\mathrm{it}}$ is the error term and the subscripts $i$ and $t$ stand for industry and year respectively

Table 9 presents the results of the supplementary analysis. In Model 1, we study the relationship between specific (statutory and demographic) attributes of female directors, female top executives (WCEO \& WCFO) and current discretionary accruals on firms that appoint at least one woman to their boards, using the four components derived through PCA instead of the original variables. In Model 2 and 3, we investigate the impact of gender diversity on earnings management by considering the combined effect of female directors, their specific (statutory and demographic) attributes and female top executives (WCEO \& WCFO). For all models in Table 9, the effects of female directors and their specific (statutory and demographic) attributes on earnings management hold after considering the influence of female executives (WCEO \&

\footnotetext{
${ }^{7}$ At this stage, it is very unusual to have both a woman CEO and a woman Chair in the same firm (0.61\% of cases). Consequently, we do not consider this scenario to be very plausible.
} 
WCFO). With regard to female top executives, female CEOs have a negative and statistically significant relationship with earnings management, albeit very small in Model 2 and Model 3. This result is at odds with the findings of Peni and Vähämaa (2010), who find that female CEOs do not influence earnings management, and is in line with studies by Gavious et al. (2012) and Ho et al. (2015). In particular, in all models of Table 9, we find that female CFOs are negatively associated with the extent of earnings management. These findings provide evidence that female CFOs are more able to influence the level of earnings management than female CEOs. Our results confirm the previous findings by Gavious et al. (2012) and Peni and Vähämaa (2010) and are consistent with the argument that female CFOs are more risk averse and adopt conservative financial reporting strategies (Francis et al., 2015).

[Please insert Table 9 here]

\section{Summary and conclusions}

This study extends the literature on the linkage between board gender diversity and earnings management, by considering specific (statutory and demographic) attributes of women directors. Aligned with the notion of the agency theory, statutory diversity indirectly enhances the board's effectiveness in creating value for shareholders by reducing agency cost (Dalton et al., 1998; John \& Senbet, 1998). In our case, statutory diversity is also expected to create value by minimizing the likelihood of earnings manipulation by managers. Further, Carter et al. (2003) argue that agency theory (statutory differences of board members) is not enough to demonstrate an actual relationship between board diversity and organizational performance. In this regard, human capital theory states that an individual's demographic attributes (e.g. experience and education level) can enhance cognitive and productive abilities, which benefit the both individual and the organization (Becker et al., 1998). Furthermore, Ben-Amar et al. (2013) propose that the effect of statutory diversity is subject to individual characteristics and demographic attributes of 
board members. Our study contributes to the literature by providing new insights into the channel (i.e. statutory and demographic attributes) through which female directors impact the extent of earnings management.

We apply the system GMM estimation approach to a matched sample of 394 French firms listed on Euronext Paris during the period 2001-2010 in order to investigate the nature of the relationship between female directors and earnings management by considering the role of statutory and demographic attributes. Consistent with prior studies, our initial findings confirm the existence of a negative link between female directorships and earnings management (Arun et al., 2015; Gavious et al., 2012; Srinidhi et al., 2011). However, when we add specific attributes in regression models, results provide evidence of a positive relationship between female directors and earnings management. Our results show that specific (statutory and demographic) attributes of women directors count more for the effective monitoring of earnings management than simply the presence and/or the percentage of women on the board. In particular, our findings underline that business expertise and audit committee memberships are key attributes of women directors for the detection and correction of earnings management practices. With regard to these findings, prior studies show that financial expertise and the appointment of female directors to audit committees minimize the probability of earnings management (Bédard \& Gendron, 2010; Srinidhi et al., 2011; Thiruvadi \& Huang, 2011). In contrast, women's chair leadership and experience are positively associated with the degree of earnings management. In accordance with the busyness and the contagion effect hypotheses, multiple directorships undermine the monitoring function of companies' board and financial outcomes (Ahn et al., 2010; Cashman et al., 2012; Fich \& Shivdasani, 2006; Lipton \& Lorsch, 1992). Further, the contagion effect proposes that earnings management is a virus that spreads from one organization to another through multiple directorships (Chiu et al., 2013). Finally, consistently with the findings of Francis et al. (2015) and Gavious et al. (2012), our supplementary analysis provides evidence to 
suggest that female executives (WCEO \& WCFO) are less likely to be associated with earnings management, with a more pronounced effect for female CFOs than for female CEOs.

Our results complement existing academic research and have important implications for managers and regulators with regard to female directorship. First, our results extend previous work and provide deep insights into the relation between board gender diversity and earnings management, by explaining the channel through which female directors affect the magnitude of earnings management. In this regard, an important implication of our findings is that the decision to appoint women to corporate boards should be based on specific criteria (e.g. business expertise and monitoring skills) rather than blind implementation of gender quotas. Studying the impact of quotas without considering the attributes of female directors may then lead to inconclusive results. Second, in the light of our results regarding the impact of women at CEO and CFO positions on the extent of earnings management, we can question whether the mandatory quota of $40 \%$ (from 2016) for women on corporate boards is a step forward in reducing gender gaps in top executive positions.

While our results offer a new perspective about the effectiveness of board gender diversity by exploring the effect of female directors' specific attributes on earnings management, we recognize at least two limitations to our study, which in turn suggest directions for future research. First, our study uses only current discretionary accruals to measure earnings management. In this regard, it will be interesting to test the association among female directors, their specific attributes and other proxies of earnings management (e.g. earnings smoothing or loss avoidance). Second, different measures women directors' attributes should be considered to better understand the influence of women directors' attributes on earnings management. For instance, we measure multiple directorships or busyness as the percentage of women directors serving on more than one board of directors simultaneously rather than the number of boards in which they are members. By doing so, we rule out the possibility to see whether the level of 
busyness affects the magnitude of earnings management or not. This would be then interesting to classify women holding multiple directorships into quartiles based on the number of boards on which each serves by considering, for example, women directors in the top quartile as "superbusy." Third, our study deals only with board gender diversity by capturing the influence of female directors' attributes. Accordingly, one should examine the influence of female executives' (CEOs and CFOs) attributes on earnings management in order to show which of their specific attributes promote more effectively the monitoring of earnings management. Another argument is that some of CFOs eventually become CEOs. By taking the similar line of research further, scholars should answer an important research questions. Is there any specific attributes of women CFOs that lead them to become CEOs and if the promotion from CFOs to CEOs moderates managers' tendency to engage in earnings management? Finally, this study considers the appointment of female directors on a voluntary rather than mandatory basis. Therefore, with regard to earnings quality, we suggest investigating the impact of female directors' appointment on a mandatory basis and the possible changes in their specific attributes after implementation of gender quotas (20\% from 2014 and 40\% from 2016).

\section{References}

Abdi, H., \& Williams, L. J. (2010). Principal component analysis. Wiley Interdisciplinary Reviews: Computational Statistics, 2(4), 433-459.

Adams, R. B., \& Ferreira, D. (2009). Women in the boardroom and their impact on governance and performance. Journal of Financial Economics, 94(2), 291-309.

Adams, R. B., Haan, J., Terjesen, S., \& Ees, H. (2015). Board diversity: Moving the field forward. Corporate Governance: An International Review, 23(2), 77-82.

Ahn, S., Jiraporn, P., \& Kim, Y. S. (2010). Multiple directorships and acquirer returns. Journal of Banking \& Finance, 34(9), 2011-2026. 
Arun, T. G., Almahrog, Y. E., \& Aribi, Z. A. (2015). Female directors and earnings management: Evidence from UK companies. International Review of Financial Analysis, 39, 137-146.

Bacon, J., \& Brown, J. (1973). Corporate directorship practices: Roles, selection and legal status of the board. New York: The Conference Board.

Barber, B. M., \& Odean, T. (2001). Boys will be boys: Gender, overconfidence, and common stock investment. Quarterly Journal of Economics, 116(1), 261-292.

Beasley, M. S. (1996). An empirical analysis of the relation between the board of director composition and financial statement fraud. The Accounting Review, 71(4), 443-465.

Becker, C., DeFond, M. L., Jiambalvo, J., \& Subramanyam, K. (1998). The effect of audit quality on earnings management. Contemporary Accounting Research, 15(1), 1-24.

Becker, G. S. (1964). Human Capital. Chicago: University of Chicago Press.

Bédard, J., Chtourou, S. M., \& Courteau, L. (2004). The effect of audit committee expertise, independence, and activity on aggressive earnings management. Auditing: A Journal of Practice \& Theory, 23(2), 13-35.

Bédard, J., \& Gendron, Y. (2010). Strengthening the financial reporting system: Can audit committees deliver? International Journal of Auditing, 14(2), 174-210.

Ben-Amar, W., Francoeur, C., Hafsi, T., \& Labelle, R. (2013). What makes better boards? A closer look at diversity and ownership. British Journal of Management, 24(1), 85-101.

Betz, M., O’Connell, L., \& Shepard, J.M. (1989). Gender differences in proclivity for unethical behavior. Journal of Business Ethics, 8(5), 321-324.

Blundell, R., \& Bond, S. (1998). Initial conditions and moment restrictions in dynamic panel data models. Journal of Econometrics, 87(1), 115-143.

Boubaker, S., \& Labégorre, F. (2008). Ownership structure, corporate governance and analyst following: A study of French listed firms. Journal of Banking \& Finance, 32(6), 961-976. 
Bruns, W. J., \& Merchant, K. A. (1990). The dangerous morality of managing earnings. Management Accounting, 72(2), 22-25.

Bushman, R., Chen, Q., Engel, E., \& Smith, A. (2004). Financial accounting information, organizational complexity and corporate governance systems. Journal of Accounting and Economics, 37, 167-201.

Byrnes, J. P., Miller, D. C., \& Schafer, W. D. (1999). Gender differences in risk taking: A metaanalysis. Psychological Bulletin, 125(3), 367-383.

Carcello, J. V., Hermanson, R. H., \& McGrath, N. T. (1992). Audit quality attributes: The perceptions of audit partners, preparers, and financial statement users. Auditing: A Journal of Practice and Theory, 11(1), 1-15.

Carter, D. A., Simkins, B. J., \& Simpson, W. G. (2003). Corporate governance, board diversity, and firm value. Financial Review, 38(1), 33-53.

Cashman, G. D., Gillan, S. L., \& Jun, C. (2012). Going overboard? On busy directors and firm value. Journal of Banking \& Finance, 36(12), 3248-3259.

Chin, C. L., Chen, Y. J., \& Hsieh, T. J. (2009). International diversification, ownership structure, legal origin, and earnings management: Evidence from Taiwan. Journal of Accounting, Auditing \& Finance, 24(2), 233-262.

Chiu, P. C., Teoh, S. H., \& Tian, F. (2013). Board interlocks and earnings management contagion. The Accounting Review, 88(3), 915-944.

Choi, J. J., Park, S. W., \& Yoo, S. S. (2007). The value of outside directors: Evidence from corporate governance reform in Korea. Journal of Financial and Quantitative Analysis, 42(4), 941-962.

Connelly, B. L., \& Van Slyke, E. J. (2012). The power and peril of board interlocks. Business Horizons, 55(5), 403-408. 
Cuervo, A. (2002). Corporate governance mechanisms: A plea for less code of good governance and more market control. Corporate Governance: An International Review, 10(2), 84-93.

Daily, C. M., \& Dalton, D. R. (1994). Bankruptcy and corporate governance: The impact of board composition and structure. Academy of Management Journal, 37(6), 1603-1617.

Daily, C. M., \& Dalton, D. R. (1997). CEO and board chair roles held jointly or separately: much ado about nothing? The Academy of Management Executive, 11(3), 11-20.

Dalton, D. R., Daily, C. M., Ellstrand, A. E., \& Johnson, J. L. (1998). Meta-analytic reviews of board composition, leadership structure, and financial performance. Strategic Management Journal, 19(3), 269-290.

Davidson, W. N., Xie, B., Xu, W., \& Ning, Y. (2007). The influence of executive age, career horizon and incentives on pre-turnover earnings management. Journal of Management \& Governance, 11(1), 45-60.

Dechow, P. M., Sloan, R. G., \& Sweeney, A. P. (1995). Detecting earnings management. The Accounting Review, 70(2), 193-225.

Duh, R. R., Lee, W. C., \& Lin, C. C. (2009). Reversing an impairment loss and earnings management: The role of corporate governance. The International Journal of Accounting, 44(2), 113-137.

Eagly, A. H., Johannesen-Schmidt, M. C., \& Van Engen, M. L. (2003). Transformational, transactional, and laissez-faire leadership styles: a meta-analysis comparing women and men. Psychological Bulletin, 129(4), 569-591.

Erhardt, N. L., Werbel, J. D., \& Shrader, C. B. (2003). Board of director diversity and firm financial performance. Corporate Governance: An International Review, 11(2), 102-111.

Faccio, M., \& Lang, L. H. (2002). The separation of ownership and control: An analysis of ultimate ownership in Western European corporations. Journal of Financial Economics, 65(3), 365-395. 
Fama, E. F., \& Jensen, M. C. (1983). Separation of ownership and control. The Journal of Law \& Economics, 26(2), 301-325.

Ferreira, D. (2015). Board diversity: Should we trust research to inform policy? Corporate Governance: An International Review, 23(2), 108-111.

Fich, E. M., \& Shivdasani, A. (2006). Are busy boards effective monitors? The Journal of Finance, 61(2), 689-724.

Francis, B., Hasan, I., Park, J. C., \& Wu, Q. (2015). Gender differences in financial reporting decision making: Evidence from accounting conservatism. Contemporary Accounting Research, 32(3), 1285-1318.

Francis, J. R., \& Wang, D. (2008). The joint effect of investor protection and Big 4 audits on earnings quality around the world. Contemporary Accounting Research, 25(1), 157-191.

Gabrielsson, J., Huse, M., \& Minichilli, A. (2007). Understanding the leadership role of the board chairperson through a team production approach. International Journal of Leadership Studies, 3(1), 21-39.

Gavious, I., Segev, E., \& Yosef, R. (2012). Female directors and earnings management in high technology firms. Pacific Accounting Review, 24(1), 4-32.

Gul, F. A., Fung, S. Y. K., \& Jaggi, B. (2009). Earnings quality: Some evidence on the role of auditor tenure and auditors' industry expertise. Journal of Accounting and Economics, 47(3), $265-287$.

Gul, F. A., Srinidhi, B., Ng, A. C. (2011). Does board gender diversity improve the informativeness of stock prices? Journal of Accounting and Economics, 51(3), 314-338.

Hambrick, D. C., \& Mason, P. A. (1984). Upper echelons: The organization as a reflection of its top managers. Academy of Management Review, 9(2), 193-206.

Healy, P. M., \& Wahlen, J. M. (1999). A review of the earnings management literature and its implications for standard setting. Accounting Horizons, 13(4), 365-383. 
Ho, S. S., Li, A. Y., Tam, K., \& Zhang, F. (2015). CEO gender, ethical leadership, and accounting conservatism. Journal of Business Ethics, 127(2), 351-370.

Hood, J. N. (2003). The relationship of leadership style and CEO values to ethical practices in organizations. Journal of Business Ethics, 43(4), 263-273.

Hwang, S., \& Kim, W. (2016). When heirs become major shareholders: Evidence on pyramiding financed by related-party sales. Journal of Corporate Finance, 41, $23-42$.

Iatridis, G. (2012). Hedging and earnings management in the light of IFRS implementation: Evidence from the UK stock market. The British Accounting Review, 44(1), 21-35.

Jaggi, B., \& Leung, S. (2007). Impact of family dominance on monitoring of earnings management by audit committees: Evidence from Hong Kong. Journal of International Accounting, Auditing and Taxation, 16(1), 27-50.

Jiang, J. X., Petroni, K. R., \& Wang, I. Y. (2010). CFOs and CEOs: Who have the most influence on earnings management? Journal of Financial Economics, 96(3), 513-526.

John, K., \& Senbet, L. W. (1998). Corporate governance and board effectiveness. Journal of Banking \& Finance, 22(4), 371-403.

Johnson, S., La Porta, R., Silanes, F. D., \& Shleifer, A. (2000). Tunneling. American Economic Review, 90(2), 22-27.

Jones, J. J. (1991). Earnings management during import relief investigations. Journal of Accounting Research, 29(2), 193-228.

Kaplan, S., Pany, K., Samuels, J., \& Zhang, J. (2009). An examination of the association between gender and reporting intentions for fraudulent financial reporting. Journal of Business Ethics, 87(1), 15-30.

Kesner, I. F. (1988). Directors' characteristics and committee membership: An investigation of type, occupation, tenure, and gender. Academy of Management Journal, 31(1), 66-84. 
Kim, H. S., \& Shim, S. (2003). Gender-based approach to the understanding of leadership roles among retail managers. Human Resource Development Quarterly, 14(3), 321-342.

Kim, K. A., Kitsabunnarat-Chatjuthamard, P., \& Nofsinger, J. R. (2007). Large shareholders, board independence, and minority shareholder rights: Evidence from Europe. Journal of Corporate Finance, 13(5), 859-880.

Klein, A. (2002). Audit committee, board of director characteristics, and earnings management. Journal of Accounting and Economics, 33(3), 375-400.

Koh, P. S. (2003). On the association between institutional ownership and aggressive corporate earnings management in Australia. The British Accounting Review, 35(2), 105-128.

Kosnik, R. D. (1990). Effects of board demography and directors' incentives on corporate greenmail decisions. Academy of Management Journal, 33(1), 129-150.

Kothari, S. P., Leone, A. J., \& Wasley, C. E. (2005). Performance matched discretionary accrual measures. Journal of Accounting and Economics, 39(1), 163-197.

Krishnan, G. V., \& Parsons, L. M. (2008). Getting to the bottom line: An exploration of gender and earnings quality. Journal of Business Ethics, 78(1-2), 65-76.

Kroll, M., Walters, B. A., \& Wright, P. (2008). Board vigilance, director experience, and corporate outcomes. Strategic Management Journal, 29(4), 363-382.

Labelle, R., Gargouri, R. M., \& Francoeur, C. (2010). Ethics, diversity management, and financial reporting quality. Journal of Business Ethics, 93(2), 335-353.

Lang, M., Raedy, J. S., \& Wilson, W. (2006). Earnings management and crosslisting: Are reconciled earnings comparable to US earnings? Journal of Accounting and Economics, 42(1), 255-283.

La Porta, R., Lopez-de-Silanes, F., \& Shleifer, A. (1999). Corporate ownership around the world. The Journal of Finance, 54(2), 471-517. 
Larcker, D. F., Richardson, S. A., \& Tuna, I. (2007). Corporate governance, accounting outcomes, and organizational performance. The Accounting Review, 82(4), 963-1008.

Licht, A. (2003). Cross-Listing and Corporate Governance: Bonding or Avoiding? Chicago Journal of International Law, 4, 122-141.

Lipton, M., \& Lorsch, J. W. (1992). A modest proposal for improved corporate governance. The Business Lawyer, 48(1), 59-77.

Liu, Q., \& Lu, Z. J. (2007). Corporate governance and earnings management in the Chinese listed companies: A tunneling perspective. Journal of Corporate Finance, 13(5), 881-906.

Machold, S., Huse, M., Minichilli, A., \& Nordqvist, M. (2011). Board leadership and strategy involvement in small firms: A team production approach. Corporate Governance: An International Review, 19(4), 368-383.

McDonald, M. L., Westphal, J. D., \& Graebner, M. E. (2008). What do they know? The effects of outside director acquisition experience on firm acquisition performance. Strategic Management Journal, 29(11), 1155-1177.

McNulty, T., Pettigrew, A., Jobome, G., \& Morris, C. (2011). The role, power and influence of company chairs. Journal of Management \& Governance, 15(1), 91-121.

Nekhili, M., Chakroun, H., \& Chtioui, T. (2016). Women's leadership and firm performance: Family versus nonfamily firms. Journal of Business Ethics, 1-26.

Nekhili, M., \& Gatfaoui, H. (2013). Are demographic attributes and firm characteristics drivers of gender diversity? Investigating women's positions on French boards of directors. Journal of Business Ethics, 118(2), 227-249.

O'Brien, R. M. (2007). A caution regarding rules of thumb for variance inflation factors. Quality \& Quantity, 41(5), 673-690.

O’Fallon, M. J., \& Butterfield, K. D. (2005). A review of the empirical ethical decision-making literature: 1996-2003. Journal of Business Ethics, 59(4), 375-413. 
Oxelheim, L., \& Randøy, T. (2003). The impact of foreign board membership on firm value. Journal of Banking \& Finance, 27(12), 2369-2392.

Papadakis, V. M., \& Barwise, P. (2002). How much do CEOs and top managers matter in strategic decision-making? British Journal of Management, 13(1), 83-95.

Park, Y. W., \& Shin, H. H. (2004). Board composition and earnings management in Canada. Journal of Corporate Finance, 10(3), 431-457.

Peni, E., \& Vähämaa, S. (2010). Female executives and earnings management. Managerial Finance, 36(7), 629-645.

Powell, M., \& Ansic, D. (1997). Gender differences in risk behaviour in financial decisionmaking: An experimental analysis. Journal of Economic Psychology, 18(6), 605-628.

Rahman, R. A., \& Ali, F. H. M. (2006). Board, audit committee, culture and earnings management: Malaysian evidence. Managerial Auditing Journal, 21(7), 783-804.

Rosenbaum, P. R., \& Rubin, D. B. (1983). The central role of the propensity score in observational studies for causal effects. Biometrika, 70(1), 41-55.

Ruigrok, W., Peck, S., \& Tacheva, S. (2007). Nationality and gender diversity on Swiss corporate boards. Corporate Governance: An International Review, 15(4), 546-557.

Sarbanes Oxley Act. (2002). Public Law No. 107-204. Washington, D.C: Government Printing Office.

Shu, P. G., Yeh, Y. H., Chiu, S. B., \& Yang, Y. W. (2015). Board external connectedness and earnings management. Asia Pacific Management Review, 20(4), 265-274.

Singh, V., Point, S., Moulin, Y., \& Davila, A. (2015). Legitimacy profiles of women directors on top French company boards. Journal of Management Development, 34(7), 803-820.

Srinidhi, B., Gul, F. A., \& Tsui, J. (2011). Female directors and earnings quality. Contemporary Accounting Research, 28(5), 1610-1644. 
Sun, J., Liu, G., \& Lan, G. (2011). Does female directorship on independent audit committees constrain earnings management? Journal of Business Ethics, 99(3), 369-382.

Thiruvadi, S., \& Huang, H. W. (2011). Audit committee gender differences and earnings management. Gender in Management: An International Journal, 26(7), 483-498.

Vafeas, N. (1999). Board meeting frequency and firm performance. Journal of Financial Economics, 53(1), 113-142.

Vasilescu, C., \& Millo, Y. (2016). Do industrial and geographic diversifications have different effects on earnings management? Evidence from UK mergers and acquisitions. International Review of Financial Analysis, 46, 33-45.

Xie, B., Davidson, W. N., \& DaDalt, P. J. (2003). Earnings management and corporate governance: The role of the board and the audit committee. Journal of Corporate Finance, 9(3), 295-316. 
Table 1

Definition of Variables

\begin{tabular}{|c|c|c|}
\hline Variable & Definition & Measure $^{8}$ \\
\hline \multicolumn{3}{|c|}{ Dependent variables: } \\
\hline$C D A$ & Current discretionary accruals & $\begin{array}{l}\text { Current discretionary accruals calculated by using modified } \\
\text { Jones model. }\end{array}$ \\
\hline \multicolumn{3}{|c|}{ Endogenous variables: } \\
\hline WDIR_NB & Number of women directors & Total number of women directors. \\
\hline WDIR $(\%)$ & Percentage of women directors & Percentage of women directors to total directors. \\
\hline WDIR_BIN & Women on board & $\begin{array}{l}\text { Dummy variable coded } 1 \text { if firm has one woman on board and } 0 \\
\text { otherwise. }\end{array}$ \\
\hline WCHAIR & Woman chair & Dummy variable coded 1 if chair is a woman and 0 otherwise. \\
\hline WIND & Independent women directors & $\begin{array}{l}\text { Percentage of non-executive independent women directors to } \\
\text { total women directors. }\end{array}$ \\
\hline WAUDCOM & $\begin{array}{l}\text { Audit committee memberships } \\
\text { held by women directors }\end{array}$ & $\begin{array}{l}\text { Percentage of women directors who are members of one of the } \\
\text { relevant operating committees to total women directors. }\end{array}$ \\
\hline WEDUC & $\begin{array}{l}\text { Education level of women } \\
\text { directors }\end{array}$ & $\begin{array}{l}\text { Percentage of women with a Master's degree or doctorate }(\mathrm{PhD}) \\
\text { to total women directors. }\end{array}$ \\
\hline WBUS & $\begin{array}{l}\text { Business education of women } \\
\text { directors }\end{array}$ & $\begin{array}{l}\text { Percentage of women with formal education, specializing in } \\
\text { business, to total women directors. }\end{array}$ \\
\hline WNAT & Nationality of women directors & Percentage of foreign women directors to total women directors. \\
\hline$W M U L$ & $\begin{array}{l}\text { Multiple directorships held by } \\
\text { women directors }\end{array}$ & $\begin{array}{l}\text { Percentage of women directors who are members of another } \\
\text { firm's board to total women directors. }\end{array}$ \\
\hline WTEN & Tenure of women directors & $\begin{array}{l}\text { Average number of years that women directors have been on the } \\
\text { board. }\end{array}$ \\
\hline WCEO & Women CEO & Dummy variable coded 1 if $\mathrm{CEO}$ is a woman and 0 otherwise. \\
\hline WCFO & Women CFO & Dummy variable coded 1 if $\mathrm{CFO}$ is a woman and 0 otherwise. \\
\hline \multicolumn{3}{|c|}{ Exogenous variables: } \\
\hline B_SIZE & Board size & Natur \\
\hline B_IND & Board independence & $\begin{array}{l}\text { Ratio of non-executive independent directors to total number of } \\
\text { directors. }\end{array}$ \\
\hline B_MEET & Board meetings & Natural logarithm of number of annual board meetings. \\
\hline$D U A L$ & CEO duality & $\begin{array}{l}\text { Dummy variable coded } 1 \text { if the CEO is board chair and } 0 \\
\text { otherwise. }\end{array}$ \\
\hline CEO_TEN & CEO tenure & No. of years worked at company before selection as CEO. \\
\hline FAM_OWN & Family ownership & Percentage of capital held by family investors. \\
\hline INST_OWN & Institutional ownership & Percentage of capital held by institutional investors. \\
\hline$B I G$ & Audit by big auditor & $\begin{array}{l}\text { Ordinal variable coded } 0 \text { if company is audited by two non-big } \\
\text { auditors, } 1 \text { if one auditor is big, and } 2 \text { if both auditors are big. }\end{array}$ \\
\hline$L E V$ & Leverage & Ratio of financial debt to total assets. \\
\hline$T Q$ & Tobin's Q & $\begin{array}{l}\text { Book value of assets minus book value of equity, plus the } \\
\text { market value of equity, scaled by the book value of assets. }\end{array}$ \\
\hline LOSS & Financial loss & Dummy variable equal to 1 if firm reports loss and 0 otherwise. \\
\hline$R \& D$ & Research and Development & Ratio of investment in R\&D to total assets. \\
\hline $\mathrm{CASH}$ & Operating cash-flow & Cash-flow from operations, scaled by total assets. \\
\hline FOR_ASSETS & Foreign assets & Ratio of foreign assets to total assets. \\
\hline BETA & Market risk & Equity beta. \\
\hline CROSS & Cross listing in U.S. markets & $\begin{array}{l}\text { Dummy variable equal to } 1 \text { if the firm is listed on one of the } \\
\text { U.S. markets (direct listing or through ADRs), and } 0 \text { otherwise. }\end{array}$ \\
\hline F_SIZE & Firm & Natural logarithm of firm's total assets. \\
\hline Industry & Industry & $\begin{array}{l}\text { A binary variable coded } 1 \text { if the company belongs to the sector } \\
\text { in question and } 0 \text { otherwise. }\end{array}$ \\
\hline
\end{tabular}

\footnotetext{
${ }^{8}$ Variables from ThomsonOne are winsorized at the $1 \%$ and $99 \%$ levels.
} 
Table 2

Panel A: Descriptive statistics for entire sample

\begin{tabular}{lccccc}
\hline & Mean & Median & $\begin{array}{c}\text { Standard } \\
\text { Deviation }\end{array}$ & Minimum & Maximum \\
\hline CDA & & & 0.103 & -0.473 & 0.337 \\
WDIR_BIN & 0.012 & 0.021 & 0.50 & 0 & 1 \\
WDIR(\%) & 0.48 & 0 & $15.06 \%$ & 0 & $75 \%$ \\
WDIR_NB & $10.72 \%$ & 0 & 0.865 & 0 & 4 \\
WCHAIR & 0.688 & 0 & $20.99 \%$ & 0 & 1 \\
WIND & $4.62 \%$ & 0 & $26.55 \%$ & 0 & 1 \\
WAUDCOM & $8.90 \%$ & 0 & $9.64 \%$ & 0 & $90.2 \%$ \\
WEDUC & $2.37 \%$ & 0 & $46.26 \%$ & 0 & 1 \\
WBUS & $46.82 \%$ & $50 \%$ & $46.67 \%$ & 0 & 1 \\
WNAT & $45.48 \%$ & $33.33 \%$ & $27.46 \%$ & 0 & 1 \\
WMUL & $9.37 \%$ & 0 & $45.42 \%$ & 0 & 1 \\
WTEN & $61.60 \%$ & 1 & 6.32 & 0 & 42 \\
WCEO & 6.51 & 5 & $18.70 \%$ & 0 & 1 \\
WCFO & $3.63 \%$ & 0 & $33.62 \%$ & 0 & 1 \\
B_SIZE (No. of directors) & $12.99 \%$ & 0 & 3.86 & 4 & 26 \\
B_IND & 7.70 & 7 & $25.40 \%$ & 0 & 1 \\
B_MEET (No. of meetings) & $27.54 \%$ & $25.5 \%$ & 3.39 & 0 & 30 \\
DUAL & 6.36 & 6 & $48.40 \%$ & 0 & 1 \\
CEO_TEN (No. of years) & $62.58 \%$ & 1 & 6.193 & 0 & 42 \\
FAM_OWN & 7.82 & 6 & $27.65 \%$ & 0 & $99.37 \%$ \\
INST_OWN & $36.84 \%$ & $39 \%$ & $26.47 \%$ & 0 & $98.63 \%$ \\
BIG & $17.93 \%$ & $4.44 \%$ & 0.659 & 0 & 2 \\
LEV & 0.922 & 1 & $16.85 \%$ & 0 & $74.45 \%$ \\
TQ & $23.10 \%$ & $21.47 \%$ & 0.830 & 0.197 & 5.38 \\
LOSS & 1.041 & 0.807 & 0 & 0 & 1 \\
R\&D & $24.17 \%$ & 0 & $0.82 \%$ & 0 & $57.22 \%$ \\
CASH & $1.81 \%$ & 0 & $10.02 \%$ & $-7.47 \%$ & $52.80 \%$ \\
FOR_ASSETS & $9.88 \%$ & $7.26 \%$ & $25.46 \%$ & 0 & $91.87 \%$ \\
BETA & $18.77 \%$ & $3.67 \%$ & 0.289 & 0.132 & 1.508 \\
F_SIZE (in billions of euros) & 0.658 & 0.642 & $28.03 \%$ & 0 & 0.560 \\
\hline
\end{tabular}

Variables are as defined in Table 1.

Panel B: Proportion of women in sample firms

\begin{tabular}{ccc}
\hline Number of women directors & Number of observations & Percentage of observations \\
\hline 0 & 1629 & 51.55 \\
1 & 1053 & 33.32 \\
2 & 357 & 11.30 \\
3 & 81 & 2.56 \\
4 & 40 & 1.27 \\
Total & 3160 & 100 \\
\hline
\end{tabular}


Table 3

Descriptive statistics by year for the percentage of women directors, the number of women directors, women directors' attributes and women in top executive positions

\begin{tabular}{|c|c|c|c|c|c|c|c|c|c|c|c|c|}
\hline Year & $\begin{array}{c}\text { WDIR } \\
(\%)\end{array}$ & $\begin{array}{c}\text { WDIR_NB } \\
\text { (number) }\end{array}$ & $\begin{array}{c}\text { WCHAIR } \\
(\%)\end{array}$ & $\begin{array}{c}\text { WIND } \\
(\%)\end{array}$ & $\begin{array}{c}\text { WAUDCOM } \\
(\%)\end{array}$ & $\begin{array}{c}\text { WEDUC } \\
(\%)\end{array}$ & $\begin{array}{c}\text { WBUS } \\
(\%)\end{array}$ & $\begin{array}{c}\text { WNAT } \\
(\%)\end{array}$ & $\begin{array}{c}\text { WMUL } \\
(\%)\end{array}$ & $\begin{array}{c}\text { WTEN } \\
\text { (number) }\end{array}$ & $\begin{array}{c}\text { WCEO } \\
(\%)\end{array}$ & $\begin{array}{c}\text { WCFO } \\
(\%)\end{array}$ \\
\hline 2001 & 8.24 & 0.50 & 3.55 & 5.43 & 0.89 & 42.78 & 34.89 & 7.89 & 57.14 & 5.17 & 2.54 & 13.28 \\
\hline 2002 & 9.35 & 0.55 & 4.06 & 5.79 & 1.25 & 44.21 & 36.83 & 7.89 & 58.52 & 5.47 & 3.04 & 13.79 \\
\hline 2003 & 9.88 & 0.59 & 3.81 & 6.09 & 1.55 & 43.32 & 39.89 & 9.22 & 61.58 & 5.89 & 3.04 & 14.28 \\
\hline 2004 & 10.29 & 0.63 & 3.55 & 6.22 & 2.29 & 45.94 & 40.53 & 9.41 & 60.93 & 6.12 & 3.04 & 13.40 \\
\hline 2005 & 10.29 & 0.66 & 4.31 & 7.01 & 2.31 & 46.85 & 44.00 & 9.30 & 59.75 & 6.13 & 3.30 & 12.57 \\
\hline 2006 & 11.03 & 0.69 & 5.08 & 7.84 & 2.56 & 48.06 & 45.90 & 9.32 & 62.74 & 6.38 & 3.81 & 12.71 \\
\hline 2007 & 11.29 & 0.72 & 5.33 & 9.28 & 2.45 & 47.81 & 46.95 & 9.41 & 62.33 & 6.73 & 4.31 & 12.04 \\
\hline 2008 & 11.34 & 0.75 & 5.58 & 9.45 & 2.67 & 47.80 & 48.88 & 8.99 & 64.10 & 7.15 & 4.57 & 12.56 \\
\hline 2009 & 11.66 & 0.78 & 5.58 & 11.48 & 3.11 & 48.86 & 50.90 & 10.10 & 63.60 & 7.50 & 4.31 & 13.05 \\
\hline 2010 & 12.61 & 0.88 & 5.33 & 14.98 & 3.71 & 48.43 & 53.91 & 10.78 & 61.69 & 7.16 & 4.31 & 12.79 \\
\hline Total & 10.72 & 0.69 & 4.62 & 8.90 & 2.37 & 46.82 & 45.48 & 9.38 & 61.59 & 6.51 & 3.63 & 12.99 \\
\hline $\begin{array}{l}\text { F-value } \\
(p \text {-value })\end{array}$ & $\begin{array}{l}2.29 * * \\
(0.014)\end{array}$ & $\begin{array}{l}5.90 * * * \\
(0.000)\end{array}$ & $\begin{array}{c}0.64 \\
(0.766)\end{array}$ & $\begin{array}{l}2.47 * * \\
(0.008)\end{array}$ & $\begin{array}{l}2.50 * * \\
(0.007)\end{array}$ & $\begin{array}{c}0.35 \\
(0.959)\end{array}$ & $\begin{array}{c}2.89 * * * \\
(0.002)\end{array}$ & $\begin{array}{c}0.17 \\
(0.997)\end{array}$ & $\begin{array}{c}0.35 \\
(0.957)\end{array}$ & $\begin{array}{l}2.35^{* *} \\
(0.012)\end{array}$ & $\begin{array}{c}0.58 \\
(0.814)\end{array}$ & $\begin{array}{c}0.12 \\
(0.999)\end{array}$ \\
\hline
\end{tabular}

Variables are as defined in Table 1.

${ }^{a}$ Analysis of variance F-value for mean difference test.

$* *, * * *$ represent significance at the $5 \%$ and $1 \%$ levels, respectively. 


\section{Table 4}

Mean difference test between gender-diverse firms and non-gender-diverse firms for the entire sample and the matched sample

\begin{tabular}{|c|c|c|c|c|c|c|}
\hline \multirow[t]{2}{*}{ Variables } & \multicolumn{3}{|c|}{ Entire Sample } & \multicolumn{3}{|c|}{ Matched Sample } \\
\hline & $\begin{array}{c}\text { Gender- } \\
\text { diverse } \\
\text { Firms }\end{array}$ & $\begin{array}{l}\text { All-male } \\
\text { firms }\end{array}$ & t-value & $\begin{array}{l}\text { Gender- } \\
\text { diverse } \\
\text { firms }\end{array}$ & $\begin{array}{l}\text { All-male } \\
\text { firms }\end{array}$ & t-value \\
\hline B_SIZE (No. of directors) & 8.107 & 7.326 & $4.07 * * *^{\mathrm{a}}$ & 7.747 & 7.651 & $-1.03^{\mathrm{a}}$ \\
\hline$B \_I N D$ & 0.303 & 0.273 & $2.96 * * *$ & 0.297 & 0.292 & 0.42 \\
\hline B_MEET (No. of meetings) & 6.453 & 6.268 & $3.85 * * * a$ & 6.337 & 6.538 & $-0.06^{\mathrm{a}}$ \\
\hline$\overline{D U A L}$ & 0.662 & 0.588 & $3.94 * * *$ & 0.630 & 0.627 & 0.10 \\
\hline CEO_TEN (No of years) & 8.632 & 7.097 & $6.33 * * * a$ & 8.227 & 8.108 & $0.11^{\mathrm{a}}$ \\
\hline FAM_OWN & 0.364 & 0.360 & 0.35 & 0.360 & 0.348 & 0.91 \\
\hline INST_OWN & 0.180 & 0.191 & -1.12 & 0.188 & 0.191 & -0.25 \\
\hline$B I G$ & 1.013 & 0.913 & $3.87 * * *$ & 0.952 & 0.967 & -0.50 \\
\hline$L E V$ & 0.230 & 0.231 & -0.37 & 0.226 & 0.224 & 0.27 \\
\hline$T Q$ & 0.997 & 1.025 & -0.91 & 1.022 & 1.016 & 0.15 \\
\hline LOSS & 0.208 & 0.267 & $-3.51 * * *$ & 0.240 & 0.236 & 0.22 \\
\hline$R \& D$ & 0.014 & 0.012 & 0.78 & 0.012 & 0.012 & 0.15 \\
\hline CASH & 0.098 & 0.096 & 0.46 & 0.097 & 0.097 & 0.04 \\
\hline FOR_ASSETS & 0.195 & 0.210 & -1.37 & 0.198 & 0.203 & -0.38 \\
\hline BETA & 0.711 & 0.673 & $3.40 * * *$ & 0.680 & 0.690 & -0.83 \\
\hline CROSS & 0.104 & 0.079 & $2.26 * *$ & 0.082 & 0.088 & -0.49 \\
\hline F_SIZE (in millions of euros) & 7.208 & 3.019 & $3.71 * * * a$ & 5.659 & 4.763 & $-0.33^{\mathrm{a}}$ \\
\hline Number of observations & 1355 & 1355 & & 947 & 947 & \\
\hline
\end{tabular}

**, *** represent significance at 0.05 and 0.01 levels respectively.

All variables are as defined in Table 1.

${ }^{\text {a }}$ t-tests are based on natural logarithm transformed values. 
Table 5

Pairwise correlation matrix

\begin{tabular}{|c|c|c|c|c|c|c|c|c|c|c|c|c|}
\hline & 1 & 2 & 3 & 4 & 5 & 6 & 7 & 8 & 9 & 10 & 11 & VIF \\
\hline 1. $C D A$ & 1.000 & & & & & & & & & & & 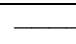 \\
\hline 2. $L C D A$ & 0.007 & 1.000 & & & & & & & & & & 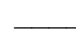 \\
\hline 3.WDIR_BIN & 0.013 & 0.013 & 1.000 & & & & & & & & & 1.03 \\
\hline 4. $\operatorname{WDIR}(\%)$ & 0.013 & 0.009 & $0.733^{*}$ & 1.000 & & & & & & & & 1.95 \\
\hline 5. WDIR_NB & 0.013 & 0.011 & $0.820 *$ & $0.819^{*}$ & 1.000 & & & & & & & 1.12 \\
\hline 6. WIND & -0.007 & -0.016 & -0.037 & $-0.156^{*}$ & -0.011 & 1.000 & & & & & & 1.23 \\
\hline 7. WAUDCOM & 0.007 & 0.003 & $0.245^{*}$ & $0.155^{*}$ & $0.231^{*}$ & $0.105^{*}$ & 1.000 & & & & & 1.16 \\
\hline 8. WCHAIR & 0.008 & 0.005 & $0.188^{*}$ & $0.198 *$ & $0.194 *$ & 0.016 & -0.041 & 1.000 & & & & 1.16 \\
\hline 9. WEDUC & 0.024 & 0.005 & 0.013 & -0.031 & -0.050 & $0.108 *$ & -0.013 & -0.041 & 1.000 & & & 1.16 \\
\hline 10. WBUS & -0.009 & -0.012 & 0.011 & $-0.127 *$ & -0.035 & $0.245^{*}$ & $0.175^{*}$ & $-0.070 *$ & $0.200^{*}$ & 1.000 & & 1.33 \\
\hline 11. WNAT & 0.011 & 0.006 & 0.015 & $-0.133^{*}$ & -0.059 & $0.088^{*}$ & 0.047 & $-0.090 *$ & $0.070^{*}$ & $0.089 *$ & 1.000 & 1.28 \\
\hline 12. WMUL & 0.004 & 0.005 & 0.058 & $-0.172 *$ & $-0.076^{*}$ & $0.107 *$ & $0.124 *$ & 0.031 & $0.135^{*}$ & $0.183^{*}$ & $0.187 *$ & 1.28 \\
\hline 13. WTEN & 0.015 & 0.009 & $0.091 *$ & $0.101^{*}$ & 0.028 & $-0.089 *$ & -0.051 & 0.006 & $-0.093^{*}$ & $-0.182 *$ & $-0.113^{*}$ & 1.27 \\
\hline 14. WCEO & 0.001 & -0.002 & $0.176^{*}$ & $0.209 *$ & $0.143^{*}$ & -0.022 & $-0.051^{*}$ & $0.112 *$ & -0.029 & -0.029 & -0.018 & 1.19 \\
\hline 15. WCFO & -0.002 & -0.001 & $0.115^{*}$ & $0.154 *$ & $0.110^{*}$ & -0.038 & -0.001 & -0.032 & -0.001 & $0.117 *$ & -0.050 & 1.16 \\
\hline 16. B_SIZE & 0.003 & 0.020 & $0.077 *$ & $-0.268^{*}$ & $0.120^{*}$ & $0.221 *$ & $0.115^{*}$ & 0.020 & -0.016 & $0.164 *$ & $0.165^{*}$ & 2.16 \\
\hline 17. $B \_I N D$ & -0.002 & 0.016 & $0.050 *$ & $-0.120^{*}$ & 0.010 & $0.176^{*}$ & $0.147 *$ & $0.099 *$ & -0.005 & $0.101^{*}$ & $0.206^{*}$ & 1.54 \\
\hline 18. B_MEET & $-0.045^{*}$ & -0.032 & $0.058 *$ & -0.012 & $0.056^{*}$ & 0.055 & $0.063^{*}$ & $-0.053 *$ & 0.027 & $0.114^{*}$ & $0.120 *$ & 1.28 \\
\hline 19. $\overline{D U} A L$ & -0.015 & -0.017 & 0.029 & 0.009 & -0.029 & $0.080 *$ & -0.040 & $-0.099 *$ & 0.036 & -0.037 & 0.023 & 1.22 \\
\hline 20. CEO_TEN & -0.007 & -0.009 & $0.111^{*}$ & $0.079 *$ & $0.126^{*}$ & $0.128 *$ & $0.098^{*}$ & $-0.064 *$ & $-0.118^{*}$ & 0.052 & 0.055 & 1.36 \\
\hline 21.FAM_OWN & 0.014 & 0.015 & 0.013 & $0.145^{*}$ & 0.045 & $-0.203^{*}$ & $-0.073^{*}$ & 0.001 & $-0.100^{*}$ & $-0.216^{*}$ & $-0.108^{*}$ & 2.05 \\
\hline 22.INST_OWN & -0.023 & -0.017 & -0.029 & $-0.058^{*}$ & $-0.057^{*}$ & 0.048 & -0.028 & 0.001 & $0.121^{*}$ & $0.065^{*}$ & 0.006 & 1.96 \\
\hline 23. $B I G$ & 0.015 & 0.020 & $0.067 *$ & $-0.114^{*}$ & $0.054^{*}$ & $0.100 *$ & $0.127 *$ & -0.040 & -0.029 & $0.140 *$ & $0.161 *$ & 1.60 \\
\hline 24. $L E V$ & 0.009 & 0.006 & -0.009 & $-0.078 *$ & -0.026 & 0.006 & $0.080^{*}$ & $-0.064 *$ & 0.010 & $0.074 *$ & 0.030 & 1.24 \\
\hline 25. $T Q$ & -0.021 & -0.004 & -0.011 & 0.008 & -0.014 & 0.040 & 0.015 & -0.033 & -0.055 & -0.062 & -0.051 & 1.18 \\
\hline 26. LOSS & $-0.096^{*}$ & -0.025 & $-0.080 *$ & -0.030 & $-0.089 *$ & -0.040 & $-0.067^{*}$ & -0.039 & 0.021 & 0.004 & 0.008 & 1.16 \\
\hline 27. $R \& D$ & -0.002 & -0.001 & 0.033 & -0.012 & -0.004 & 0.020 & -0.014 & 0.042 & 0.011 & $-0.098^{*}$ & 0.017 & 1.15 \\
\hline 28. $C A S H$ & 0.003 & 0.010 & -0.015 & -0.019 & -0.022 & 0.001 & -0.011 & 0.001 & -0.052 & -0.016 & -0.014 & 1.16 \\
\hline 29. FOR_ASSETS & -0.040 & -0.040 & -0.037 & $-0.151 *$ & $-0.045^{*}$ & $0.154 *$ & $0.080^{*}$ & -0.040 & 0.031 & $0.099 *$ & $0.312^{*}$ & 1.47 \\
\hline 30. BETA & -0.006 & -0.015 & $0.062 *$ & $-0.072 *$ & $0.051 *$ & $0.203^{*}$ & $0.090^{*}$ & -0.012 & -0.012 & $0.122 *$ & $0.176^{*}$ & 1.79 \\
\hline 31. CROSS & 0.002 & 0.001 & 0.043 & $-0.084 *$ & 0.027 & 0.047 & $0.080^{*}$ & -0.013 & 0.020 & $0.147 *$ & $0.218^{*}$ & 1.33 \\
\hline 32. F_SIZE & 0.020 & 0.015 & $0.078 *$ & $-0.167 *$ & $0.075^{*}$ & $0.214 *$ & $0.121 *$ & 0.006 & -0.053 & $0.141 *$ & $0.235^{*}$ & 2.96 \\
\hline
\end{tabular}

* represent significance at 0.01 level.

All variables are as defined in Table 1. 
Table 5 (Continued)

\begin{tabular}{|c|c|c|c|c|c|c|c|c|c|c|c|c|}
\hline & 12 & 13 & 14 & 15 & \multicolumn{2}{|r|}{16} & 17 & 18 & 19 & 20 & 21 & 22 \\
\hline 12. WMUL & 1.000 & & & & & & & & & & & \\
\hline 13. WTEN & 0.000 & 1.000 & & & & & & & & & & \\
\hline 14. WCEO & -0.058 & $0.077 *$ & 1.000 & & & & & & & & & \\
\hline 15. WCFO & 0.024 & 0.044 & $0.075^{*}$ & 1.000 & & & & & & & & \\
\hline 16. $B \_S I Z E$ & $0.206^{*}$ & $-0.136^{*}$ & $-0.099 *$ & $-0.144 *$ & & 1.000 & & & & & & \\
\hline 17. B_IND & 0.050 & -0.031 & $-0.072 *$ & -0.032 & & $0.365^{*}$ & 1.000 & & & & & \\
\hline 18. B_MEET & $-0.079 *$ & -0.033 & 0.036 & -0.018 & & $0.137 *$ & $0.115^{*}$ & 1.000 & & & & \\
\hline 19. $\overline{D U} A L$ & $0.078 *$ & 0.058 & 0.036 & $0.082 *$ & & $-0.079 *$ & $-0.156^{*}$ & 0.021 & 1.000 & & & \\
\hline 20. CEO_TEN & 0.037 & $0.250 *$ & 0.034 & -0.001 & & $0.111 *$ & $0.098 *$ & $0.045^{*}$ & $0.118^{*}$ & 1.000 & & \\
\hline 21. FAM_OWN & $-0.126^{*}$ & $0.154 *$ & $0.148 *$ & $0.104 *$ & & $-0.220 *$ & $-0.189 *$ & $-0.104 *$ & -0.014 & $0.052 *$ & 1.000 & \\
\hline 22.INST_OWN & $0.158^{*}$ & $-0.170 *$ & $-0.077 *$ & $-0.066^{*}$ & & 0.025 & 0.011 & $-0.058 *$ & $0.102 *$ & $-0.087^{*}$ & $-0.537 *$ & 1.000 \\
\hline 23. $B I G$ & $0.139 *$ & -0.059 & $-0.126^{*}$ & -0.039 & & $0.480 *$ & $0.309^{*}$ & $0.112 *$ & $-0.076^{*}$ & $0.073^{*}$ & $-0.140 *$ & 0.042 \\
\hline 24. $L E V$ & $0.118^{*}$ & -0.063 & -0.019 & $-0.084 *$ & & $0.154 *$ & 0.025 & $0.088^{*}$ & -0.009 & 0.019 & $-0.058 *$ & $0.055^{*}$ \\
\hline 25. $T Q$ & -0.050 & -0.001 & 0.012 & 0.011 & & $-0.062 *$ & -0.040 & 0.007 & 0.007 & 0.014 & 0.028 & $-0.065^{*}$ \\
\hline 26. $L O S S$ & -0.008 & -0.022 & -0.019 & -0.020 & & $-0.149 *$ & $-0.085^{*}$ & 0.032 & 0.015 & $-0.074^{*}$ & -0.026 & 0.010 \\
\hline 27. $R \& D$ & -0.022 & $0.095^{*}$ & 0.016 & -0.023 & & 0.032 & $0.062 *$ & 0.045 & 0.028 & 0.021 & 0.025 & $-0.069 *$ \\
\hline 28. $C A S H$ & -0.041 & 0.051 & 0.008 & 0.006 & & $-0.053^{*}$ & $0.095^{*}$ & $0.083^{*}$ & 0.030 & 0.045 & -0.001 & $-0.091^{*}$ \\
\hline 29.FOR_ASSETS & $0.113^{*}$ & -0.025 & $-0.076^{*}$ & $-0.080 *$ & & $0.336^{*}$ & $0.270 *$ & $0.157^{*}$ & -0.021 & $0.137 *$ & $-0.198 *$ & 0.027 \\
\hline 30. BETA & $0.091^{*}$ & 0.018 & -0.017 & $-0.055^{*}$ & & $0.266^{*}$ & $0.229 *$ & $0.240^{*}$ & $-0.045^{*}$ & $0.095^{*}$ & $-0.234^{*}$ & $-0.081^{*}$ \\
\hline 31. CROSS & $0.089 *$ & $-0.076^{*}$ & $-0.063 *$ & $-0.092 *$ & & $0.307 *$ & $0.202 *$ & $0.138^{*}$ & -0.033 & -0.002 & $-0.148 *$ & $-0.051 *$ \\
\hline 32. F_SIZE & $0.170^{*}$ & -0.012 & $-0.071 *$ & $-0.117 *$ & & $0.547 *$ & $0.424 *$ & $0.230^{*}$ & $-0.169 *$ & $0.137 *$ & $-0.106^{*}$ & $-0.277^{*}$ \\
\hline & 23 & 24 & 25 & 26 & 27 & 28 & 29 & 30 & 31 & 32 & & \\
\hline 23. BIG & 1.000 & & & & & & & & & & & \\
\hline 24. $L E V$ & 0.045 & 1.000 & & & & & & & & & & \\
\hline $25 . T Q$ & 0.023 & $-0.168 *$ & 1.000 & & & & & & & & & \\
\hline 26. LOSS & $-0.046^{*}$ & 0.040 & $-0.074 *$ & 1.000 & & & & & & & & \\
\hline 27. $R \& D$ & $0.058^{*}$ & $-0.051 *$ & $0.125^{*}$ & 0.018 & 1.000 & & & & & & & \\
\hline 28. $C A S H$ & $0.070^{*}$ & $-0.269 *$ & $0.208^{*}$ & 0.014 & $0.205^{*}$ & 1.000 & & & & & & \\
\hline 29.FOR_ASSETS & $0.310^{*}$ & $0.071^{*}$ & -0.028 & $-0.048^{*}$ & $0.051 *$ & -0.009 & 1.000 & & & & & \\
\hline 30. BETA & $0.284^{*}$ & -0.025 & $0.130 *$ & $0.081 *$ & $0.074 *$ & $0.150^{*}$ & $0.302 *$ & 1.000 & & & & \\
\hline 31. CROSS & $0.203^{*}$ & $0.054 *$ & 0.035 & 0.028 & $0.061 *$ & $0.050 *$ & $0.177^{*}$ & $0.278^{*}$ & 1.000 & & & \\
\hline 32. F_SIZE & $0.412 *$ & $0.166^{*}$ & 0.016 & $-0.155^{*}$ & $0.054 *$ & $0.068^{*}$ & $0.376^{*}$ & $0.444^{*}$ & $0.337 *$ & 1.000 & & \\
\hline
\end{tabular}

* represent significance at 0.01 level.

All variables are as defined in Table 1 
Table 6

Derived components

\begin{tabular}{|c|c|c|}
\hline Variables & Eigenvalue & Description \\
\hline Component 1: EXPERTISE (21.7\%) & 1.736 & $\begin{array}{l}\text { WCHAIR }(-0.150) \\
\text { WIND }(0.399) \\
\text { WAUDCOM }(0.302) \\
\text { WEDUC }(0.334) \\
\text { WBUS }(\mathbf{0 . 5 3 1}) \\
\text { WNAT }(0.320) \\
\text { WMUL }(0.370) \\
\text { WTEN }(-0.306)\end{array}$ \\
\hline Component 2: LEADERSHIP (13.2\%) & 1.060 & $\begin{array}{l}\text { WCHAIR }(\mathbf{0 . 6 7 1}) \\
\text { WIND }(0.344) \\
\text { WAUDCOM }(-0.378) \\
\text { WEDUC }(0.174) \\
\text { WBUS }(0.181) \\
\text { WNAT }(-0.323) \\
\text { WMUL }(-0.174) \\
\text { WTEN }(-0.297)\end{array}$ \\
\hline Component 3: EXPERIENCE (13\%) & 1.041 & $\begin{array}{l}\text { WCHAIR }(0.503) \\
\text { WIND }(0.115) \\
\text { WAUDCOM }(0.076) \\
\text { WEDUC }(-0.140) \\
\text { WBUS }(-0.087) \\
\text { WNAT }(0.114) \\
\text { WMULTI (0.622) } \\
\text { WTEN }(\mathbf{0 . 5 4 8})\end{array}$ \\
\hline Component 4: AUDCOM_MEMB (12.7\%) & 1.015 & $\begin{array}{l}\text { WCHAIR }(0.070) \\
\text { WIND }(0.243) \\
\text { WAUDCOM }(\mathbf{0 . 6 6 0}) \\
\text { WEDUC }(-0.416) \\
\text { WBUS }(0.163) \\
\text { WNAT }(-0.437) \\
\text { WMULTI }(-0.187) \\
\text { WTEN }(-0.006)\end{array}$ \\
\hline
\end{tabular}

Note: The first number in parentheses after the factor label is the variance accounted for by the component. The numbers in parentheses after the original variables explanation are the component loadings. The extraction method is principal component analysis and the factor loading coefficient cut-off is 0.50 .

All variables are as defined in Table 1. 
Table 7

System GMM regression of earnings management on women directorship

\begin{tabular}{|c|c|c|c|c|c|c|}
\hline \multirow[t]{2}{*}{ Variables } & \multicolumn{2}{|c|}{ Model 1} & \multicolumn{2}{|c|}{ Model 2} & \multicolumn{2}{|c|}{ Model 3} \\
\hline & Coef. & t-test & Coef. & t-test & Coef. & t-test \\
\hline Lag CDA & $-0.009 * * *$ & -5.57 & $-0.001 * * *$ & -5.72 & $-0.011 * * *$ & -8.37 \\
\hline WDIR_BIN & $-0.118 * * *$ & -7.89 & & & & \\
\hline $\operatorname{WDIR}(\%)$ & & & $-0.561 * * *$ & -11.16 & & \\
\hline WDIR_NB & & & & & $-0.044 * * *$ & -5.91 \\
\hline B_SIZE & $-0.020 * *$ & -2.08 & $-0.070 * * *$ & -6.69 & -0.006 & -0.74 \\
\hline B_IND & $-0.058 * * *$ & -3.67 & $-0.060 * * *$ & -3.61 & $-0.055 * * *$ & -4.38 \\
\hline B_MEET & $-0.042 * * *$ & -5.91 & $-0.042 * * *$ & -6.03 & $-0.036 * * *$ & -6.06 \\
\hline$D U A L$ & 0.003 & 0.37 & -0.011 & -1.39 & -0.010 & -1.56 \\
\hline CEO_TEN & $-0.037 * * *$ & -5.15 & $-0.018 * * *$ & -2.87 & $-0.030 * * *$ & -5.13 \\
\hline FAM_OWN & 0.010 & 0.88 & 0.007 & 0.44 & -0.002 & -0.20 \\
\hline INST_OWN & 0.008 & 0.46 & -0.018 & -1.11 & -0.018 & -1.34 \\
\hline$B I G$ & 0.011 & 1.46 & $0.016^{* *}$ & 2.37 & 0.010 & 1.74 \\
\hline$L E V$ & $-0.077 * * *$ & -6.35 & $-0.073 * * *$ & -6.34 & $-0.082 * * *$ & -7.79 \\
\hline$T Q$ & -0.007 & -1.75 & $-0.008 * *$ & -2.28 & $-0.008 * * *$ & -2.70 \\
\hline LOSS & $-0.121 * * *$ & -24.37 & $-0.130 * * *$ & -26.57 & $-0.120 * * *$ & -27.41 \\
\hline$R \& D$ & $-0.213 * * *$ & -3.11 & $-0.207 * * *$ & -3.70 & $-0.228 * * *$ & -4.28 \\
\hline CASH & $-0.197 * * *$ & -6.83 & $-0.233 * * *$ & -7.92 & $-0.214 * * *$ & -8.20 \\
\hline FOR_ASSETS & 0.026 & 1.44 & 0.007 & 0.05 & 0.005 & 0.36 \\
\hline BETA & 0.005 & 0.35 & 0.015 & 1.14 & 0.016 & 1.46 \\
\hline CROSS & 0.030 & 1.86 & 0.024 & 1.73 & 0.024 & 1.90 \\
\hline F_SIZE & 0.002 & 1.81 & 0.008 & 0.55 & 0.001 & 1.49 \\
\hline Intercept & $0.311 * * *$ & 7.49 & $0.410 * * *$ & 10.08 & $0.260 * * *$ & 7.98 \\
\hline Industry (?) & \multicolumn{2}{|c|}{ Yes } & \multicolumn{2}{|c|}{ Yes } & \multicolumn{2}{|c|}{ Yes } \\
\hline Years (?) & \multirow{2}{*}{\multicolumn{2}{|c|}{$\begin{array}{l}\text { Yes } \\
1751\end{array}$}} & \multicolumn{2}{|c|}{ Yes } & \multicolumn{2}{|c|}{ Yes } \\
\hline Number of observations & & & \multicolumn{2}{|c|}{1751} & \multicolumn{2}{|c|}{1751} \\
\hline$F($ Prob $>F)$ & \multicolumn{2}{|c|}{$7015.63(p=0.000)$} & \multicolumn{2}{|c|}{$8718.96(p=0.004)$} & \multicolumn{2}{|c|}{$6568.28(p=0.000)$} \\
\hline Arellano-Bond test $\mathrm{AR}(1)(\mathrm{z}, p$-value): & \multirow{2}{*}{\multicolumn{2}{|c|}{$\begin{array}{l}-2.87(p=0.004) \\
-1.01(p=0.314)\end{array}$}} & \multicolumn{2}{|c|}{$-2.91(p=0.000)$} & \multicolumn{2}{|c|}{$-2.83(p=0.005)$} \\
\hline Arellano-Bond test $\mathrm{AR}(2)(\mathrm{z}, p$-value $)$ : & & & \multirow{2}{*}{\multicolumn{2}{|c|}{$2964.18(p=0.000)$}} & \multicolumn{2}{|c|}{$-1.05(p=0.296)$} \\
\hline Sargan test (Chi-square, $p$-value): & \multicolumn{2}{|c|}{$2960.80(p=0.000)$} & & & 2999.78 & $=0.000)$ \\
\hline Hansen test (Chi-square, $p$-value): & \multicolumn{2}{|c|}{$165.82(p=0.271)$} & \multicolumn{2}{|c|}{$167.09(p=0.231)$} & \multicolumn{2}{|c|}{$\begin{aligned} 9999.18(p=0.000) \\
169.06(p=0.332)\end{aligned}$} \\
\hline
\end{tabular}
$* *, * * *$ represent significance at 0.05 and 0.01 levels respectively.

All variables are as defined in Table 1 
Table 8

System GMM regression of earnings management on women directorship and attributes derived from PCA

\begin{tabular}{|c|c|c|c|c|c|c|}
\hline \multirow[t]{2}{*}{ Variables } & \multicolumn{2}{|c|}{ Model 1} & \multicolumn{2}{|c|}{ Model 2} & \multicolumn{2}{|c|}{ Model 3} \\
\hline & Coef. & t-test & Coef. & $\mathrm{t}$-test & Coef. & t-test \\
\hline $\operatorname{Lag} C D A$ & $0.070 * * *$ & 27.38 & $0.085 * * *$ & 13.11 & $0.082 * * *$ & 12.96 \\
\hline $\operatorname{WDIR}(\%)$ & & & $0.366^{* * *}$ & 21.90 & & \\
\hline WDIR_NB & & & & & $0.054 * * *$ & 20.04 \\
\hline AUDCO & $-0.010 * * *$ & -10.47 & $-0.016 * * *$ & -10.11 & $-0.013 * * *$ & -6.37 \\
\hline LEADERSHIP & $0.016 * * *$ & 14.41 & $0.025 * * *$ & 15.87 & $0.024 * * *$ & 13.47 \\
\hline EXPERTISE & $-0.004 * * *$ & -4.74 & $-0.009 * * *$ & -7.43 & $-0.006^{* * *}$ & -3.74 \\
\hline EXPERIENCE & $0.029 * * *$ & 19.20 & $0.020 * * *$ & 12.05 & $0.017 * * *$ & 11.83 \\
\hline B_SIZE & $-0.016 * * *$ & -5.04 & $0.042 * * *$ & 8.11 & $-0.033 * * *$ & -7.71 \\
\hline B_IND & $-0.030 * * *$ & -6.84 & $-0.015^{* * *}$ & -2.61 & -0.004 & -0.87 \\
\hline$B \_M E E T$ & 0.002 & 1.50 & $-0.006 * *$ & -2.20 & -0.005 & -1.63 \\
\hline $\bar{D} U A L$ & $0.008 * * *$ & 3.35 & $0.019 * * *$ & 6.82 & $0.019 * * *$ & 6.83 \\
\hline CEO_TEN & $-0.004 * *$ & -2.27 & -0.002 & -0.77 & -0.004 & -1.50 \\
\hline$F A M \_O W N$ & $-0.078 * * *$ & -19.70 & $-0.082 * * *$ & -11.03 & $-0.065 * * *$ & -8.35 \\
\hline INST_OWN & $-0.056 * * *$ & -10.28 & $-0.061 * * *$ & -9.75 & $-0.050 * * *$ & -9.71 \\
\hline$B I G$ & $0.012 * * *$ & 7.18 & $0.007 * * *$ & 2.72 & $0.008 * * *$ & 3.56 \\
\hline$L E V$ & $-0.040 * * *$ & -5.82 & -0.012 & -1.38 & -0.015 & -1.55 \\
\hline$T Q$ & $-0.002 * * *$ & -4.34 & 0.001 & 0.56 & 0.002 & 1.59 \\
\hline LOSS & $-0.102 * * *$ & -54.28 & $-0.098 * * *$ & -41.13 & $-0.098 * * *$ & -38.49 \\
\hline$R \& D$ & 0.060 & 1.72 & 0.060 & 1.31 & $0.111 * *$ & 2.25 \\
\hline CASH & $-0.168 * * *$ & -13.20 & $-0.143 * * *$ & -7.99 & $-0.141 * * *$ & -9.29 \\
\hline FOR_ASSETS & $0.008 * *$ & 2.00 & $0.016^{* * *}$ & 2.63 & $0.028 * * *$ & 5.45 \\
\hline$B E T A$ & $-0.027 * * *$ & -9.67 & $-0.015^{* * *}$ & -3.30 & $-0.016^{* * *}$ & -3.63 \\
\hline CROSS & $0.050 * * *$ & 17.35 & $0.040 * * *$ & 7.81 & $0.037 * * *$ & 7.57 \\
\hline F_SIZE & $-0.001 * * *$ & -3.37 & $0.001 * *$ & 2.30 & 0.000 & 0.97 \\
\hline Intercept & $0.070 * * *$ & 5.22 & $-0.160 * * *$ & -6.90 & $-0.009 * * *$ & -0.50 \\
\hline Industry (?) & \multicolumn{2}{|c|}{ Yes } & \multicolumn{2}{|c|}{ Yes } & \multicolumn{2}{|c|}{ Yes } \\
\hline Years (?) & \multicolumn{2}{|c|}{ Yes } & \multicolumn{2}{|c|}{ Yes } & \multicolumn{2}{|c|}{ Yes } \\
\hline Number of observations & \multicolumn{2}{|c|}{886} & \multicolumn{2}{|c|}{886} & \multicolumn{2}{|c|}{886} \\
\hline $\mathrm{F}($ Prob $>\mathrm{F})$ & \multicolumn{2}{|c|}{$10321.53(p=0.000)$} & \multicolumn{2}{|c|}{$88858.18(p=0.000)$} & \multicolumn{2}{|c|}{$60070.59(p=0.000)$} \\
\hline Arellano-Bond test $\mathrm{AR}(1)(\mathrm{z}, p$-value): & \multicolumn{2}{|c|}{$-3.33(p=0.001)$} & \multicolumn{2}{|c|}{$-3.67(p=0.000)$} & \multicolumn{2}{|c|}{$-3.56(p=0.000)$} \\
\hline Arellano-Bond test $\mathrm{AR}(2)(\mathrm{z}, p$-value $)$ : & \multicolumn{2}{|c|}{$0.08(p=0.934)$} & \multicolumn{2}{|c|}{$-0.19(p=0.849)$} & \multicolumn{2}{|c|}{$-0.16(p=0.870)$} \\
\hline Sargan test (Chi-square, $p$-value): & \multirow{2}{*}{\multicolumn{2}{|c|}{$1226.03(p=0.000)$}} & \multicolumn{2}{|c|}{$1183.83(p=0.000)$} & \multicolumn{2}{|c|}{$1199.65(p=0.000)$} \\
\hline Hansen test (Chi-square, $p$-value): & $163.45(p=0.286)$ & & \multicolumn{2}{|c|}{$155.73(p=0.220)$} & \multicolumn{2}{|c|}{$145.20(p=0.433)$} \\
\hline
\end{tabular}

**, *** represent significance at 0.05 and 0.01 levels respectively.

All variables are as defined in Table 1 


\section{Table 9}

System GMM regression of earnings management on women directorship, attributes derived from PCA and female executives

\begin{tabular}{|c|c|c|c|c|c|c|}
\hline \multirow[t]{2}{*}{ Variables } & \multicolumn{2}{|c|}{ Model 1} & \multicolumn{2}{|c|}{ Model 2} & \multicolumn{2}{|c|}{ Model 3} \\
\hline & Coef. & t-test & Coef. & t-test & Coef. & t-test \\
\hline Lag CDA & $0.075 * * *$ & 6.24 & $0.075 * * *$ & 7.45 & $0.074 * * *$ & 7.90 \\
\hline WDIR $(\%)$ & & & $0.696^{* * *}$ & 29.61 & & \\
\hline$W D I R \_N B$ & & & & & $0.107 * * *$ & 20.38 \\
\hline AUDCOM_MEMB & $-0.011 * * *$ & -2.93 & $-0.014 * * *$ & -4.18 & $-0.010 * * *$ & -3.15 \\
\hline LEADERSHIP & $0.053 * * *$ & 11.64 & $0.032 * * *$ & 16.29 & $0.037 * * *$ & 16.86 \\
\hline EXPERTISE & $-0.012 * * *$ & -2.59 & $-0.018 * * *$ & -5.35 & $-0.011^{* * *}$ & -3.02 \\
\hline EXPERIENCE & $0.024^{* * *}$ & 4.89 & $0.015 * * *$ & 5.06 & $0.027 * * *$ & 8.94 \\
\hline WCEO & $-0.075 * * *$ & -5.56 & -0.026 & -1.81 & 0.013 & 0.91 \\
\hline WCFO & $-0.216^{* * *}$ & -15.93 & $-0.065 * * *$ & -6.25 & $-0.125^{* * *}$ & -11.94 \\
\hline B_SIZE & $-0.028 * * *$ & -3.76 & $0.094 * * *$ & 13.22 & $-0.051 * * *$ & -7.35 \\
\hline B_IND & -0.013 & -1.11 & -0.006 & -0.66 & 0.008 & 0.81 \\
\hline B_MEET & $-0.011 * *$ & -2.02 & $-0.009 * *$ & -1.97 & -0.010 & -1.92 \\
\hline$D U A L$ & $0.032 * * *$ & 4.66 & $0.034 * * *$ & 5.66 & $0.045 * * *$ & 7.20 \\
\hline CEO_TEN & 0.009 & 1.68 & -0.005 & -1.29 & $-0.012 * * *$ & -2.78 \\
\hline FAM_OWN & -0.005 & -0.39 & $-0.075 * * *$ & -7.75 & $-0.060 * * *$ & -5.00 \\
\hline INST_OWN & $-0.040 * * *$ & -3.26 & $-0.045 * * *$ & -4.57 & $-0.046 * * *$ & -4.04 \\
\hline$B I G$ & $0.027 * * *$ & 5.23 & $0.008 * *$ & 2.39 & $0.019 * *$ & 4.22 \\
\hline$L E V$ & -0.016 & -0.91 & 0.032 & 1.83 & 0.025 & 1.48 \\
\hline$T Q$ & 0.001 & 0.05 & $0.007^{* *}$ & 2.24 & $0.007 * *$ & 2.07 \\
\hline LOSS & $-0.091 * * *$ & -16.67 & $-0.090 * * *$ & -19.89 & $-0.093 * * *$ & -16.97 \\
\hline$R \& D$ & $-0.274 * * *$ & -5.32 & $-0.109 * * *$ & -3.43 & $-0.148^{* * *}$ & -3.57 \\
\hline CASH & $-0.192 * * *$ & -5.88 & $-0.104 * * *$ & -3.95 & $-0.162 * *$ & -5.88 \\
\hline FOR_ASSETS & $0.052 * * *$ & 3.32 & $0.025^{* *}$ & 2.33 & 0.020 & 1.75 \\
\hline BETA & -0.013 & -1.05 & $-0.024 * * *$ & -2.68 & $-0.026^{* *}$ & -2.45 \\
\hline CROSS & $0.037 * * *$ & 3.21 & $0.026 * * *$ & 2.57 & $0.041 * * *$ & 4.28 \\
\hline F_SIZE & $-0.002 * *$ & -2.38 & $0.003 * * *$ & 4.05 & 0.005 & 0.62 \\
\hline Intercept & 0.030 & 0.75 & $-0.396 * * *$ & -9.62 & -0.064 & -1.43 \\
\hline Industry (?) & \multicolumn{2}{|c|}{ Yes } & \multicolumn{2}{|c|}{ Yes } & \multicolumn{2}{|c|}{ Yes } \\
\hline Years (?) & \multicolumn{2}{|c|}{ Yes } & \multicolumn{2}{|c|}{ Yes } & \multicolumn{2}{|c|}{ Yes } \\
\hline Number of observations & \multicolumn{2}{|c|}{886} & \multicolumn{2}{|c|}{886} & \multicolumn{2}{|c|}{886} \\
\hline $\mathrm{F}($ Prob > F $)$ & \multicolumn{2}{|c|}{$1486.91(p=0.000)$} & \multicolumn{2}{|c|}{$1003.54(p=0.000)$} & \multicolumn{2}{|c|}{$5923.61(p=0.000)$} \\
\hline Arellano-Bond test $\mathrm{AR}(1)(\mathrm{z}, p$-value): & \multicolumn{2}{|c|}{$-3.42(p=0.001)$} & \multicolumn{2}{|c|}{$-3.86(p=0.000)$} & \multicolumn{2}{|c|}{$-3.85(p=0.000)$} \\
\hline Arellano-Bond test $\operatorname{AR}(2)(z, p-$ value $)$ : & \multicolumn{2}{|c|}{$0.03(p=0.979)$} & \multicolumn{2}{|c|}{$-0.26(p=0.792)$} & \multicolumn{2}{|c|}{$-0.27(p=0.785)$} \\
\hline Sargan test (Chi-square, $p$-value): & \multirow{2}{*}{\multicolumn{2}{|c|}{$1276.75(p=0.000)$}} & \multirow{2}{*}{\multicolumn{2}{|c|}{$\begin{array}{r}1194.76(p=0.000) \\
128.83(p=0.274)\end{array}$}} & \multicolumn{2}{|c|}{$1212.42(p=0.000)$} \\
\hline Hansen test (Chi-square, $p$-value): & & & & & $127.67 t$ & $=0.299)$ \\
\hline
\end{tabular}

**, *** represent significance at 0.05 and 0.01 levels respectively.

All variables are as defined in Table 1 